Hydrol. Earth Syst. Sci. Discuss., 4, 555-588, 2007 www.hydrol-earth-syst-sci-discuss.net/4/555/2007/ (C) Author(s) 2007. This work is licensed under a Creative Commons License.
Hydrology and Earth System Sciences Discussions

Papers published in Hydrology and Earth System Sciences Discussions are under open-access review for the journal Hydrology and Earth System Sciences

\title{
Weathering rates and origin of inorganic carbon as influenced by river regulation in the boreal sub-arctic region of Sweden
}

\section{J. Brink ${ }^{1}$, C. Humborg ${ }^{2}$, J. Sahlberg ${ }^{3}$, L. Rahm ${ }^{4}$, and C.-M. Mörth ${ }^{1}$}

${ }^{1}$ Dept. of Geology and Geochemistry, Stockholm University, 10691 Stockholm, Sweden

${ }^{2}$ Dept. of Environmental assessment, Stockholm University, 10691 Stockholm, Sweden

${ }^{3} \mathrm{SMHI}$, Swedish Meterological and Hydrological Institute, Norrköping, 60176 Norrköping,

Sweden

${ }^{4}$ Dept. of Water and Environmental Studies, University of Linköping, 58183 Linköping, Sweden

Received: 18 December 2006 - Accepted: 14 February 2007 - Published: 13 March 2007

Correspondence to: C.-M. Mörth (magnus.morth@geo.su.se)

HESSD

4, 555-588, 2007

Weathering rates and origin of inorganic carbon

J. Brink et al.

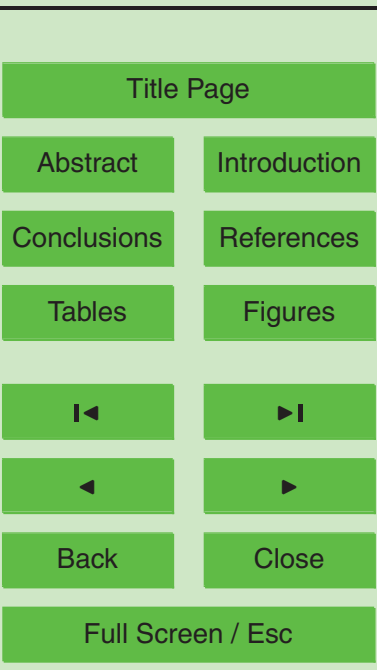

Printer-friendly Version

Interactive Discussion 


\section{Abstract}

Major environmental stressors of boreal and sub-arctic rivers are hydrological changes and global warming and both factors will significantly influence the future evolution of the river chemistry in high latitudes. We tested the hypothesis whether lower concen5 trations of dissolved constituents observed in regulated rivers come along with lower weathering rates, though specific discharge as a major force for physical erosion and weathering is often higher in regulated river systems. In this study the river chemistry, weathering rates and related carbon dioxide consumption in two large watersheds in the sub arctic region of Sweden, one regulated river (Lule River) and one unregulated (Kalix River), was investigated. Weathering ra sheds are shown to be different; the silicate weathering rate in Kalix River catchment is almost $30 \%$ higher than in the Lule River catchment. This is most likely a result of constructing large reservoirs in the former river valleys inundating the alluvial deposits and thus decreasing soil/water contact resulting in lower weathering rates. Furthermore, the difference observed in weathering rates between lowland regions and headwaters suggests that weathering in sub arctic boreal climates is controlled by the residence time for soil water rock interactions followed by lithology. The chemistry in the two rivers shows weathering of silicates as the origin for $68 \%$ of the inorganic carbon in the Lule River and $74 \%$ for Kalix River.

The study clearly shows that river regulation significantly decreases alkalinity export to the sea because lower weathering rates gives less carbon dioxide ending up as DIC. By considering sources for inorganic carbon we here report that the inorganic carbon load that originates from respiration of organic matter in soils makes up of $30 \%$ and $35 \%$ of the total C export for the watersheds of the Kalix River and Lule River, carbon load carbon must be considered when studying climate changes on the organic carbon load since effects from increased degradation of organic matter may lead to more weathering (higher production of DIC).

HESSD

4, 555-588, 2007

\section{Weathering rates and origin of inorganic carbon \\ J. Brink et al.}

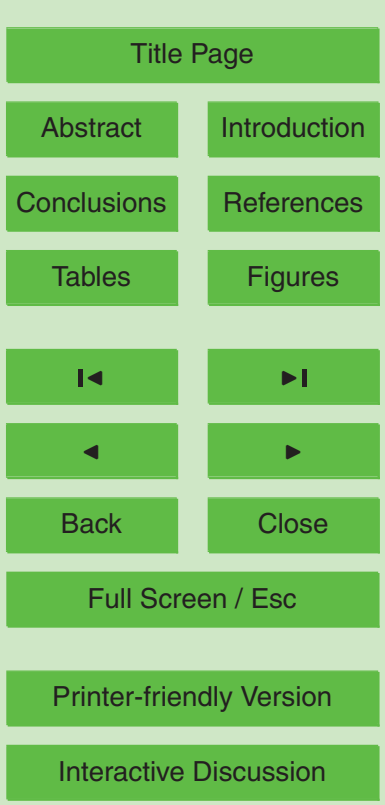

EGU 


\section{Introduction}

River exports of dissolved solids ( $\mathrm{Si}, \mathrm{Ca}, \mathrm{Mg}, \mathrm{Na}, \mathrm{K}, \mathrm{HCO}_{3}$ ) are closely linked to weathering rates of silicate and carbonate minerals (Berner and Berner, 1996; Humborg et al., 1997), and river chemistry supply and retention reflect the processes in soils and

along the aquatic continuum. The chemical weathering rate of silicate minerals is controlled by a proton promoted part and a ligand promoted part (Amrhein and Suarez, 1988). The most important proton source is carbonic acid originating from either $(i)$ atmospheric $\mathrm{CO}_{2}$ that is dissolved in water, or (ii) respiratory formed $\mathrm{CO}_{2}$ originating from the degradation of organic matter. Other significant factors controlling the weathering regime in a river catchment is temperature, specific runoff (Berner and Berner, 1996) and physical erosion (Gaillardet et al., 1999).

Comparisons between regulated and non-regulated rivers have often shown that regulated rivers have lower concentrations of major elements (Humborg et al., 2000, 2004) and it has been argued that the lower concentrations in boreal watersheds of northern 15 Sweden are an effect of "less" weathering in the regulated watersheds (Humborg et al., 2004). However, lower concentrations of dissolved constituents in regulated rivers may also be related to a high specific discharge, i.e. a dilution effect, since rivers with a higher specific discharge are preferentially regulated due to higher energy gains. Thus, the main aim of this study was to compare specific weathering yields $\left(\mathrm{mol} \mathrm{km} \mathrm{kr}^{-2} \mathrm{yr}^{-1}\right.$ ) between a regulated and an unperturbed watershed, since these can be directly related to possible differences in mass fluxes of major dissolved constituents such as $\mathrm{Si}$ and alkalinity. Special emphasis on these weathering related constituents have been given, since the $\mathrm{Si}$ export influences diatom production in coastal seas and the alkalinity export (mainly as $\mathrm{HCO}_{3}^{-}$) is a significant variable for regional carbon budgets (Raymond 25 and Cole, 2003).

River geochemistry has, in many studies since the pioneering work of Garrels and Mackenzie (1971), given important information about denudation rates of biogeochemical elements and the related consumption of atmospheric $\mathrm{CO}_{2}$. Several different ap-
HESSD

4, 555-588, 2007

Weathering rates and origin of inorganic carbon

J. Brink et al.

Title Page

Abstract

Introduction

Conclusions

Tables

References

Figures

14

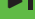

4

Back

Close
Printer-friendly Version

Interactive Discussion 
proaches have been applied for these calculations ranging from studies of small rivers draining one rock type under a given climate condition (Amiotte-Suchet and Probst, 1993; Bluth and Kump, 1994; White and Blum, 1995) to a more global perspective, studying the very large rivers' geochemistry (Berner et al., 1983; Gaillardet et al., 1997;

5 Holland, 1978). One such study is of the Amazon River by Gaillardet et al. (1999) and Mortatti and Probst (2003). It stressed the importance of physical erosion and its relation to chemical weathering. Similar relations have also been observed in small catchments of the Canadian Shield that is comparable to our investigation area (Millot et al., 2002). In this study we have used a method presented by Mortatti and Probst (2003), to 10 compare (i) river chemistry, (ii) weathering rates and (iii) consumption/sequestration of $\mathrm{CO}_{2}$ during weathering of primary minerals between two boreal sub arctic rivers, Lule River (heavily regulated) and Kalix River (unregulated).

\section{Material and methods}

\subsection{Study area}

15 The Lule and Kalix River basins are located in the sub arctic boreal climate zone of northern Sweden. In total, the two drainage basins cover an area of nearly $50000 \mathrm{~km}^{2}$ (Lule River: $25225 \mathrm{~km}^{2}$ and Kalix River: $23846 \mathrm{~km}^{2}$ ). The rivers have their headwaters in northwest, close to the Norwegian border in the Scandinavian Caledonides, and they flow southward to southeast into the foothills and the boreal forested lowland of the Precambrian basement. They finally drain into the Bothnian Bay (Northern part of the Baltic Sea). Lule River has been regulated since the early 1900 s with the latest regulation in the 1970s. In 1923 the Akkajaure reservoir, sometimes also called the Suorva dam, (Fig. 1) was erected, today with water level amplitude of $33 \mathrm{~m}$ and an active storage capacity of $5.9 \mathrm{~km}^{3}$ of water. Except for the water regulation of Lule River, the two rivers can be considered as relatively unperturbed due to the sparse population. Therefore, these two rivers are optimal for investigations of controlling weathering
HESSD

$4,555-588,2007$

\section{Weathering rates and origin of inorganic carbon \\ J. Brink et al.}

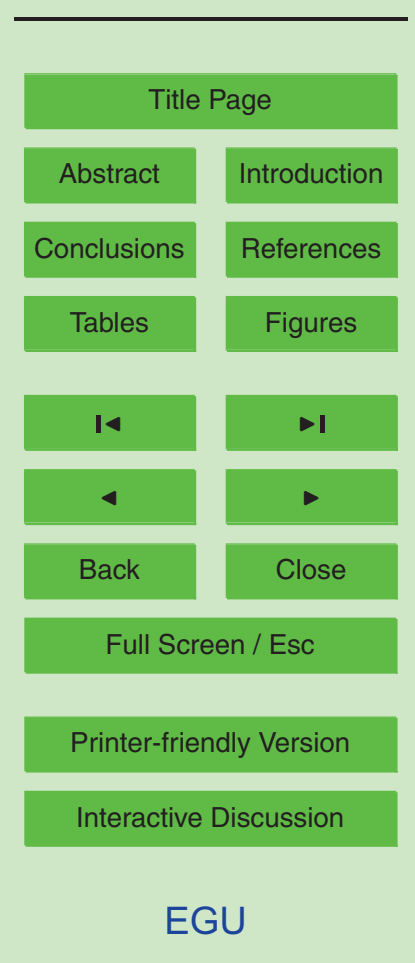


factors in a sub arctic boreal environment. The rivers drain through similar geological settings, which make them an excellent investigation area to study the effects of hydrological alterations on river biogeochemistry as such.

The mean water discharge for Lule River and Kalix River is $17.6 \mathrm{~km}^{3} \mathrm{yr}^{-1}$ and $59.3 \mathrm{~km}^{3} \mathrm{yr}^{-1}$ respectively, and the mean annual precipitation for the basins is $698 \mathrm{~mm}$ and $544 \mathrm{~mm}$, respectively. Westerly winds from the Atlantic Ocean are prevailing delivering high precipitation in the headwater of Lule River, with mean precipitation of $1200 \mathrm{~mm} \mathrm{yr}^{-1}$. Rain shadow in the headwater of Kalix River gives a mean annual precipitation of only half of that observed in headwater of Lule River (Table 1). Most of the 10 precipitation is accumulated as snow; this accumulation starts normally in October and ends in June. The snow melts during early summer, which results in high discharge during a short time period (May to July). The cold climate with annual mean air temperatures close to $-2^{\circ} \mathrm{C}$ in the headwaters and about $+1^{\circ} \mathrm{C}$ at the river mouths (Table 1), also leads to high runoff ratios as seen for headwaters in Table 1. The overall hydrology 15 is presented in Table 1.

In the headwater areas above the tree line (about 650-800 $\mathrm{m}$ a.s.l.), the vegetation cover is mainly alpine heath. Barren lands, with no soil layer, and glaciers are also found. In the forested lowland the soil thickness becomes greater. The soils are dominated by till containing minerals like Quartz, K-feldspar, K-mica and Plagioclase with a minor percentage of mafic minerals, like Amphibole, Clorite, Epidote and Pyroxene. Alluvial deposits are found along the main river valleys where soil thickness is found several times larger than in the upstream catchments; this is especially true for the headwaters. The forested lowland is vegetated with shrub and brushwood, deciduous and coniferous forests but also mires. Muddus River is a good example of a lowland tributary to Lule River. It is a typical boreal river influenced by its large amount (42\%) of mires (Humborg et al., 2004).
HESSD

$4,555-588,2007$

\section{Weathering rates and origin of inorganic carbon}

J. Brink et al.

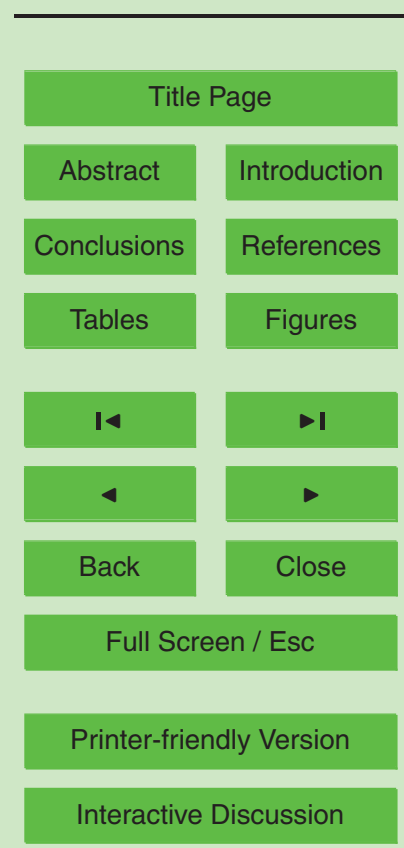

EGU 
HESSD

The Swedish Caledonides are divided into five main tectonic units; the uppermost thrust rocks, the upper thrust rocks, the middle thrust rocks, the lower thrust rocks and the autochthonous sedimentary series in the easterly marginal zone of the Caledonian 5 thrust succession. These sedimentary series consist of phanerozoic sediments, mainly sandstone and shale (Gee and Zachrisson, 1979; Kulling, 1964, 1972, 1982).

The Akkajaure reservoir is situated in a U-shaped valley, surrounded by the middle thrust rocks, the Akkajaure Nappe Complex, which is the dominant tectonic unit in the headwater of Lule River (Gee and Zachrisson, 1979; Kulling, 1964, 1982). Precambrian gneissic granitoids, gneissic granites, granites and syenites, dominate the Precambrian acid igneous rocks of the middle thrust rocks within the headwater of the Akkajaure reservoir (Björklund, 1985; Kulling, 1964). In the catchment of Vuojatätno, located in the southwestern part of the basin, the uppermost and upper thrust rocks dominate, here consisting of minerals like mica-schist, calcareous mica-schist, marbles 15 and minor occurrences of amphibolites (Björklund, 1985; Kulling, 1964). Calcite and Dolomite occur frequently (Kulling, 1982).

In Sweden the highest mountains are located within the upper thrust complex, e.g. the massif of Akka (2010 m a.s.I.), in the headwater of Lule River, and the Kebnekaise Mountains (2103 m a.s.I.), in the headwater of Kalix River (Kulling, 1964). The upper thrust rocks are dominating in the headwater of Kalix River. Andreasson and Gee (1989) have identified three major tectonic units in the area: the Tarfala amphibolite, the Storglaciären gneiss and the Kebne dyke complex. The dyke complex consists of mafic rocks with subordinated metasediment. The mafic rocks of the highest mountains have been referred to as amphibolites by Kulling (1964). However, Andreasson and Gee (1989) suggested that the Kebnekaise massif might be dominated by dolerite. At lower altitudes in the downward succession, the Storglaciären gneiss is exposed consisting of mylonitic granitoids. Below this rock there is the Tarfala amphibolite. These rock successions are probably similar for the surrounding mountains i.e. Ladtjovagge val-
4, 555-588, 2007

\section{Weathering rates and origin of inorganic carbon \\ J. Brink et al.}

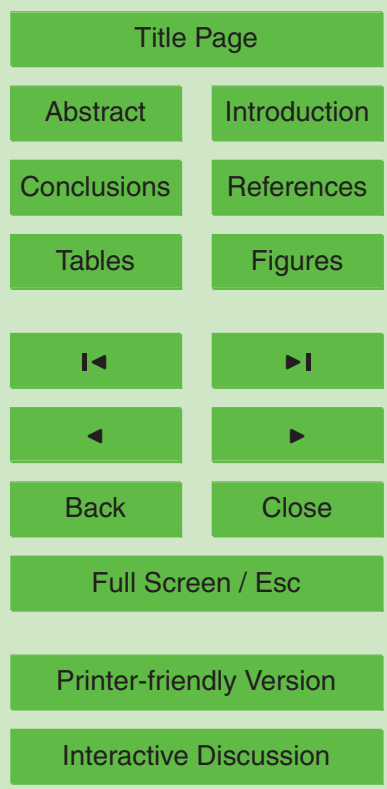

EGU 
ley. The Precambrian crystalline basement is visible in the valley of Tarfalavagge and Ladtjovagge. The percent of main bedrock type in each investigated catchment, except for Killingi in Kaitum River, is presented in Table 2.

\section{Sampling and methodology}

5 In the headwaters of the Lule River catchment all main tributaries to the Akkajaure reservoir were sampled; additionally, depth profiles in the reservoir itself were also taken. In the Kalix River Basin samples were taken in the Ladtjo River at the inlet of Lake Paijtas (Fig. 1). The sampling period was from June 2000 to April 2001. Samples were taken at three yearly hydrological events: base flow (winter flow) in April, spring 10 flood in June and summer/autumn flow in September/October.

The water samples were collected directly at the surface by syringes or with a Teflon coated Ruttner-type sampler (Limnos), pre-washed in $0.1 \mathrm{M}$ hydrochloric acid and carefully rinsed with ultra-clean water. The water samples analyzed for dissolved elements were filtrated through pre-washed cellulose membrane filters ( 0.45 um Millipore) and 15 collected in acid washed polyethylene bottles. For conservation of cations, one $\mathrm{ml}$ of SUPRAPURE nitric acid (65\%) (MERCK 1.00441.100) was added for every $100 \mathrm{ml}$ of water in the field. Dissolved element concentrations were analysed with ICP-OES (inductively coupled plasma-optical emission spectrometer) Varian Vista Pro Ax, with an analytical precision of better than $4 \%$ (typically less than $2 \%$ ), based on measurements of certified standards. The anions were analysed with IC (Ion Chromatography, Dionex DX-300 system equipped with an AS14 column and using electric suppression). The analytical precision for IC analysis was also better than 4\% (but typically lower), based on measurements of certified standards.

Alkalinity of filtrated water samples was determined by a modified back titration 25 method (Almgren et al., 1983), using an automatic titration unit equipped with; a Metrohm $632 \mathrm{pH}-$ Meter and a reference electrode, Metrohm 6.0219.100, a Metrohm 655 Dosimat and a Metrohm 614 Impulsomat. The samples were weighted and titrated

HESSD

4, 555-588, 2007

\section{Weathering rates and origin of inorganic carbon \\ J. Brink et al.}

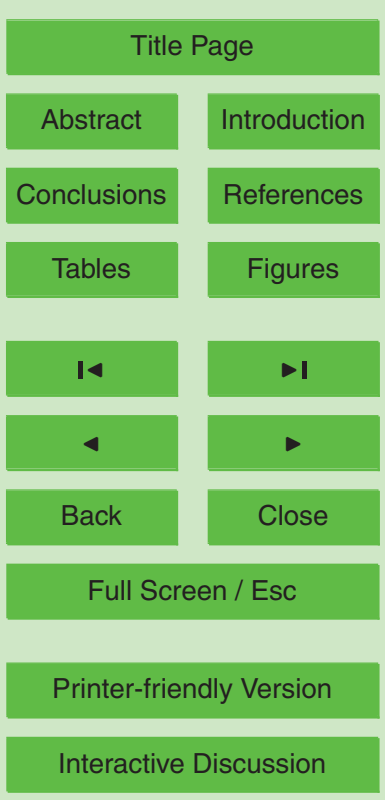

EGU 
with acid in room temperature down to $\mathrm{pH} 4.0$, with $0.1 \mathrm{M}$ hydrochloric acid (Titrisol, MERCK). The alkalinity (as $\mathrm{HCO}_{3}^{-}$) was calculated from the difference between the amount of acid added and the excess acid present. The excess acid was determined by adding 0.1M sodium hydroxide (Titrisol, MERCK) to $\mathrm{pH} 5.6$.

5 Total organic carbon, TOC, was determined on unfiltrated water samples using a Shimadzu TOC-5000-analyzer (fluid injection, catalytic combustion).

Selected water samples were analyzed for their mass ratio of ${ }^{87} \mathrm{Sr} /{ }^{86} \mathrm{Sr}$. This was done after filtration of the water samples and an ion-exchange to enrich the Sr concentration. Thereafter the collected Sr was coated on wire filaments. The Sr isotope - composition was analyzed by using a thermal ionisation (solid source) mass spectrometer (TIMS, Finnigan Mat 262) at IFE, Oslo, Norway. The precision was better than \pm 0.000001 .

\subsection{Calculation of water discharge and precipitation volume}

The flow discharge and precipitation volume, for water mass balance calculations has been quantified with a hydrological model, called the HBV model. The model was developed at the Swedish Meteorological and Hydrological Institute (SMHI) in the early 1970s (Bergström and Forsman, 1973) for runoff simulation and hydrological forecasting. The model has been modified many times since then, but the main modelling philosophy has been unchanged. Details of its application on the Akkajaure catchment are found in Sahlberg (2004).

\subsection{Precipitation chemistry and calculation of fluxes}

To be able to calculate weathering rates good estimates of water fluxes (precipitation and runoff) are essential. When watersheds are located in areas where precipitation is not strongly acidic, the chemical weathering can be considered as a function of:

\section{HESSD}

4, 555-588, 2007

\section{Weathering rates and origin of inorganic carbon \\ J. Brink et al.}

Title Page

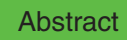

Introduction

Conclusions

Tables

References

Figures

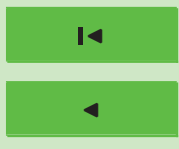

$\rightarrow$

Back

Close

\section{Full Screen / Esc}

Printer-friendly Version

Interactive Discussion

This type of approach does not consider cation exchange or biomass uptake, which 
are considered to be in steady state (Drever and Clow, 1995). The major difficulty is to get valid deposition figures for the whole catchment. This simplified relation is realistic only if the deposition encompasses all atmospheric inputs including bulk precipitation, dry deposition and throughfall.

5 The element concentrations in the precipitation (bulk deposition), from nearby meteorological stations were used to calculate the deposition (Table 3). The headwater precipitation concentrations in Lule River are mean values from three different stations, one situated in Norway, the European Monitoring and Evaluation Programme (EMEP)-station Trustervatn (http://www.emep.int/), which is situated at $65^{\circ} 50^{\prime} \mathrm{N}$ and $1013^{\circ} 55^{\prime} \mathrm{E}$, near the Atlantic coast at an altitude of 439 meters above sea level. The other two are situated in Sweden; the Swedish Programme for Environmental Monitoring (PMK)-station Abisko (http://www.ivl.se/miljo/), $68^{\circ} 21^{\prime} \mathrm{N}$ and $19^{\circ} 03^{\prime} \mathrm{E}$, and the EMEPstation Ammarnäs (http://www.emep.int/), $65^{\circ} 58^{\prime} \mathrm{N}$ and $16^{\circ} 12^{\prime} \mathrm{E}$. Abisko was used for the headwaters in Kalix River, and the PMK-station Pålkem (http://www.ivl.se/miljo/), land of Lule River.

Due to the large drainage area of the Lule River, ranging from the west near the Atlantic coast to the west coast of the Bothnian Bay (Baltic Sea), spatial variations in rain water composition make it difficult to calculate the mean elemental deposition for the whole area (i.e. at the river mouth) without separating the area into smaller regions. We divided the area in a headwater area, contributing to nearly half of the total runoff in the basin, and a lowland region, contributing the other half. For the elemental deposition of the Lule River basin, a mean value has been taken between the precipitation chemistry at the PMK-station Pålkem, here representing the lowland 25 region of Lule River basin and the headwater elemental concentration in rainwater. The main difference between the used precipitation chemistry stations are caused by the distance to the Atlantic and the sea salt contribution. The high concentrations of nutrients $\left(\mathrm{NO}_{3}\right.$ and $\left.\mathrm{NH}_{4}\right)$ and sulphate $\left(\mathrm{SO}_{4}\right)$ in rainwater close to the Bothnian Bay coast are probably caused by anthropogenic pollution.
HESSD

4, 555-588, 2007

\section{Weathering rates and origin of inorganic carbon \\ J. Brink et al.}

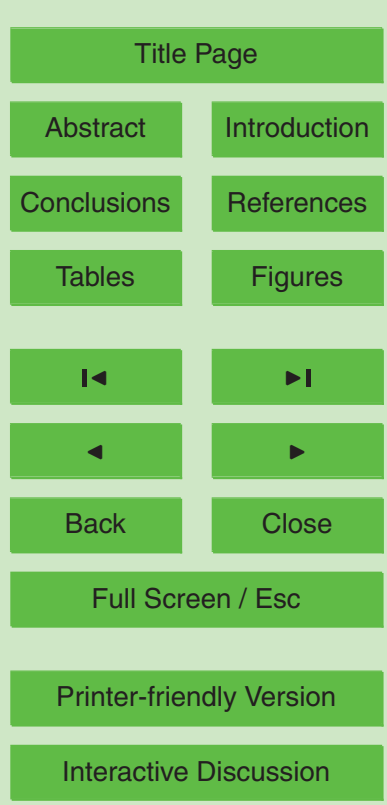

EGU 


\subsection{Weathering rates and $\mathrm{CO}_{2}$ consumption}

River geochemistry contains information about both the supply of ions to the liquid phase, i.e., by the lithology, and the retention of ions, i.e., removal of ions during formation of clay minerals for example. The procedure for calculation of total atmo5 spheric/soil $\mathrm{CO}_{2}$ consumed by rock weathering of carbonates and silicates, as well as alkalinity $\left(\mathrm{HCO}_{3}^{-}\right)$follows the hypothesis outlined by Mortatti and Probst (2003). The consumed atmospheric/soil $\mathrm{CO}_{2}$ is as follows (for an explanation of used abbreviations see Table 4);

$\mathrm{CO}_{2 \mathrm{~atm}}=\mathrm{Na}_{\text {sil }}+\mathrm{K}_{\text {sil }}+2 \mathrm{Ca}_{\text {sil }}+2 \mathrm{Mg}_{\text {sil }}+\mathrm{Mg}_{\text {carb }}+\mathrm{Ca}_{\text {carb }}$

and the produced alkalinity/ $\mathrm{HCO}_{3}^{-}$;

$\mathrm{HCO}_{3 \text { total }}=\mathrm{Na}_{\text {sil }}+\mathrm{K}_{\text {sil }}+2 \mathrm{Ca}_{\text {sil }}+2 \mathrm{Mg}_{\text {sil }}+2 \mathrm{Mg}_{\text {carb }}+2 \mathrm{Ca}_{\text {carb }}$

The difficulty with this approach is to distinguish the $\mathrm{Ca}$ and $\mathrm{Mg}$ silicate contribution of the total fluxes of $\mathrm{Ca}$ and $\mathrm{Mg}$. Attempts have been made; by using the ion ratio $(\mathrm{Na}+\mathrm{K}) /(\mathrm{Ca}+\mathrm{Mg})$ in stream water draining only silicate rocks (Probst et al., 1994), or by using the average ratio $\mathrm{Ca} / \mathrm{Na}$ and $\mathrm{Mg} / \mathrm{Na}$ of runoff water draining a granite shield basement (Drever, 1997). We have used the ion ratios $\mathrm{Ca} / \mathrm{Na}=1.10$ and $\mathrm{Mg} / \mathrm{Na}=0.43$, calculated for Råne River, which drains an area in between Lule- and Kalix River Basins where the bedrock consists mainly of Precambrian silicate rocks (Humborg et al., 2004). The $\mathrm{Ca} / \mathrm{Na}$ and $\mathrm{Mg} / \mathrm{Na}$ ratios multiplied by the sodium concentration at the different locations represent the $\mathrm{Ca}$ and $\mathrm{Mg}$ derived from silicates.

All $\mathrm{HCO}_{3}^{-}$produced by silicate weathering (see Reaction 3-5 below) is of atmospheric/soil origin, whereas for carbonate weathering (Reaction 6) only half of bicarbonate released is of atmospheric/soil $\mathrm{CO}_{2}$ origin. This can be summarized in the following reactions;

- incongruent weathering of albite to kaolinite
HESSD

4, 555-588, 2007

Weathering rates and origin of inorganic carbon

J. Brink et al.

Title Page

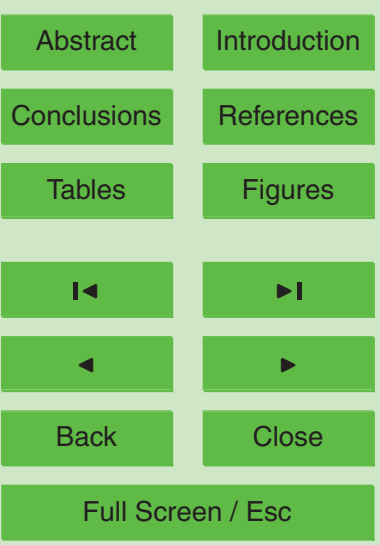

Printer-friendly Version

Interactive Discussion 
$\mathrm{NaAlSi} \mathrm{O}_{8}+2 \mathrm{CO}_{2}+11 \mathrm{H}_{2} \mathrm{O} \Rightarrow \mathrm{Al}_{2} \mathrm{Si}_{2} \mathrm{O}_{5}(\mathrm{OH})_{4}+2 \mathrm{HCO}_{3}^{-}+2 \mathrm{Na}^{+}+4 \mathrm{H}_{4} \mathrm{SiO}_{4}$

- incongruent dissolution of K-feldspar to kaolinte

$2 \mathrm{KAISi}_{3} \mathrm{O}_{8}+2 \mathrm{CO}_{2}+11 \mathrm{H}_{2} \mathrm{O} \Rightarrow \mathrm{Al}_{2} \mathrm{Si}_{2} \mathrm{O}_{5}(\mathrm{OH})_{4}+2 \mathrm{HCO}_{3}^{-}+2 \mathrm{~K}^{+}+4 \mathrm{H}_{4} \mathrm{SiO}_{4}$

- incongruent dissolution of Ca-plagioclase to kaolinte:

$5 \mathrm{CaAl}_{2} \mathrm{Si}_{2} \mathrm{O}_{8}+2 \mathrm{CO}_{2}+3 \mathrm{H}_{2} \mathrm{O} \Rightarrow \mathrm{Al}_{2} \mathrm{Si}_{2} \mathrm{O}_{5}(\mathrm{OH})_{4}+2 \mathrm{HCO}_{3}^{-}+\mathrm{Ca}_{2}^{+}$

- calcite dissolution:

$\mathrm{CaCO}_{3}+\mathrm{CO}_{2}+\mathrm{H}_{2} \mathrm{O} \Rightarrow \mathrm{Ca}_{2}^{+}+2 \mathrm{HCO}_{3}^{-}$

HESSD

4, 555-588, 2007

To get the chemical weathering rate, the specific fluxes (in mol km${ }^{-2} \mathrm{yr}^{-1}$ ), are related to the drainage area (here the rate is given for the cationic silicate fluxes):

$10 \mathrm{~F}_{\text {cationic }}$ sil $=\left(\mathrm{Na}_{\text {sil }}+\mathrm{K}_{\text {sil }}+2 \mathrm{Ca}_{\text {sil }}+2 \mathrm{Mg}_{\text {sil }}\right) /$ drainagearea

$\mathrm{F}_{\text {cationic }} \mathrm{carb}=\left(\mathrm{Ca}_{\text {carb }}+\mathrm{Mg}_{\text {carb }}\right) /$ drainagearea

Weathering rates and origin of inorganic carbon

J. Brink et al.

\subsection{1 $\mathrm{CO}_{2}$ consumption during weathering of minerals}

The mass budget of $\mathrm{CO}_{2}$ consumption due to rock weathering (silicate and carbonate rock weathering) becomes:

$\mathrm{CO}_{2 \mathrm{~atm}}=\mathrm{Na}_{\text {sil }}+\mathrm{K}_{\text {sil }}+2 \mathrm{Ca}_{\text {sil }}+2 \mathrm{Mg}_{\text {sil }}+\mathrm{Mg}_{\text {carb }}+\mathrm{Ca}_{\text {carb }}$

and the mass budget of $\mathrm{CO}_{2}$ consumption and formation from silicate rock weathering:

$\mathrm{CO}_{2 \text { sil }}=\mathrm{Na}_{\text {sil }}+\mathrm{K}_{\text {sil }}+2 \mathrm{Ca}_{\text {sil }}+2 \mathrm{Mg}_{\text {sil }}$

The $\mathrm{CO}_{2 x}$ Eq. (9) to (10) relate the stoichiometry for the weathering reactions 3 to 6 , where cations are "produced" from reactions with protons that originates from carbonic acid (that has its origin from atmospheric/soil $\mathrm{CO}_{2}$ ).

Title Page

Abstract

Introduction

Conclusions

References

Tables

Figures

14

$\rightarrow 1$

4

Back

Close

Full Screen / Esc

Printer-friendly Version

Interactive Discussion 
In Table 5 physical parameters, major element concentrations, TOC, Sr isotope ratios for the dissolved load of each tributary, the Akkajaure reservoir and the river mouths of Kalix River and Lule River, are presented. Three different hydrological events are shown; spring flow in May/June, summer flow in August/September and base flow in 5 November to April. Water chemistry of Muddus River, Kaitum River and the Lule and Kalix River mouths are presented with yearly mean values for the period 1985 to 2003. The average charge balance (in $\mu \mathrm{eq}$ ) between total dissolved cations ( $\Sigma$ cations $=\mathrm{Na}^{+}$ $+\mathrm{K}^{+}+2 \mathrm{Ca}^{2+}+2 \mathrm{Mg}^{2+}$ ) and total dissolved anions ( anions $=\mathrm{Cl}^{-}+2 \mathrm{SO}_{4}^{2-}+\mathrm{HCO}_{3}^{-}$) was better than $10 \%$ (see Table 5). The ionic strength of all investigated waters is very 10 low.

\section{Results}

On average, $\mathrm{Ca}^{2+}$ is the most abundant major cation in all streams, ranging from 37-112 umol L $\mathrm{u}^{-1}$, followed by $\mathrm{Na}^{+}\left(24-85 \mathrm{umolL}^{-1}\right), \mathrm{Mg}^{2+}\left(9-48 \mathrm{umol} \mathrm{L}^{-1}\right)$ and $\mathrm{K}^{+}$ (9-31 umol $\left.\mathrm{L}^{-1}\right)$, except for Valtajåkka in the headwater of Lule River which is dom15 inated by $\mathrm{Na}^{+}\left(51 \mathrm{umolL}^{1}\right)$, followed by $\mathrm{Ca}^{2+}\left(37 \mathrm{umolL}^{-1}\right), \mathrm{Mg}^{2+}\left(19 \mathrm{umol} \mathrm{L}^{-1}\right)$ and $\mathrm{K}^{+}$(13.3 umol $\mathrm{L}^{-1}$ ). For anions the most abundant anion is $\mathrm{HCO}_{3}^{-}$in both Kalix River and Lule River Basin. In Kalix River basin $\mathrm{SO}_{4}^{2-}$ dominates over $\mathrm{Cl}^{-}$and vice versa in Lule River basin. The high concentration of $\mathrm{Cl}^{-}$and $\mathrm{Na}^{+}$in headwater of Lule River basin compared to headwater concentration of Kalix River basin (almost half of the concentration of $\mathrm{Na}^{+}$and $\mathrm{Cl}^{-}$compared to Lule River), reflect the contribution from precipitation (see Table 3). The highest major element concentrations are observed during winter (baseflow) when the discharge is low.

The highest $\mathrm{Ca}^{2+}$ concentration is measured at the River mouth of Kalix River (112.1 umol L $\left.{ }^{-1}\right)$. Vuojatätno in the headwater of Lule River basin has a similar concen25 tration of $\mathrm{Ca}^{2+}, 105.7 \mathrm{umol} \mathrm{L}^{-1}$. The lowest average $\mathrm{Ca}^{2+}$ concentration is observed in Valtajåkka (37.4 umol $\mathrm{L}^{-1}$ ). Valtajåkka also has the lowest average concentration of $\mathrm{HCO}_{3}^{-}$. Under winter base flow Valtajåkka has the highest measured silica concentra-
HESSD

$4,555-588,2007$

Weathering rates and origin of inorganic carbon

J. Brink et al.

Title Page

Abstract

Introduction

Conclusions

Tables

References

Figures

14

$\rightarrow$ I

4

Back

Close

Full Screen / Esc

Printer-friendly Version

Interactive Discussion 
tion in Lule River headwater, 71 umol L $^{-1}$. The lowest average molar concentration of silica is observed in Sitas and Vuojatätno, followed by Akkajaure reservoir ( $15 \mathrm{umol} \mathrm{L}^{-1}$ ) and Lule River mouth $\left(40 \mathrm{umol} \mathrm{L}^{-1}\right)$. The silica concentration is generally doubled in Kalix River Basin, at the river mouth about $100 \mathrm{umol} \mathrm{L}^{-1}$. The highest average molar 5 concentration of silica is in Muddus River $\left(114\right.$ umol L$\left.^{-1}\right)$, which also have the highest TOC concentration of $5.5 \mathrm{mg} \mathrm{L}^{-1}$ or $0.46 \mathrm{mmol} \mathrm{L}^{-1}$. Previous reported studies of river chemistry and the relation between silica and TOC (Humborg et al., 2004) is also valid in the investigated streams (Fig. 2) and thus DOC/TOC can be used as a proxy for soil/water contact resulting in elevated silica concentrations.

The ternary diagrams (Figs. 3a-b) show the overall dominance of calcite in the headwater streams relative to the cations derived from silicates, despite the very small proportions of carbonates relative to silicate bedrock in the studied areas (Table 2). The carbonate chemistry dominance observed in the Akkajaure reservoir is a reflection of the river chemistry in Vuojatätno, which contributes to about $70 \%$ of the water in Akka5 jaure reservoir (Table 1).

In the $\mathrm{Na}$ normalized mixing diagrams (Figs. $4 \mathrm{~b}$ and $\mathrm{c}$ ) the tributaries, Akkajaure reservoir and River mouth is plotted. The used end members ratios for carbonates in this study are estimated using data on small rivers draining one single lithology (carbonates, silicates and evaporites). These end member ratios are taken from Gaillardet et al. (1997); the silicate end member ratio for $\mathrm{Ca} / \mathrm{Na}$ is $0.35 \pm 0.25, \mathrm{Mg} / \mathrm{Na}=0.24 \pm 0.16$, $\mathrm{Sr} / \mathrm{Na}=3 \pm 1 \times 10^{-3}, \mathrm{HCO}_{3} / \mathrm{Na}=1 \pm 1$ and ${ }^{87} \mathrm{Sr} /{ }^{86} \mathrm{Sr}=0.73 \pm 0.01$. The used end member ratios for carbonates in this study are $\mathrm{Ca} / \mathrm{Na}=45 \pm 25, \mathrm{Mg} / \mathrm{Na}=15 \pm 10, \mathrm{Sr} / \mathrm{Na}=$ $40 \pm 20 \times 10^{-3}, \mathrm{HCO}_{3} / \mathrm{Na}=90 \pm 40$ and ${ }^{87} \mathrm{Sr} /{ }^{86} \mathrm{Sr}=0.7075 \pm 0.0005$, and the evaporite end member ratios are $\mathrm{Ca} / \mathrm{Na}=0.17 \pm 0.09, \mathrm{Mg} / \mathrm{Na}=0.02 \pm 0.01, \mathrm{Sr} / \mathrm{Na}=3 \pm 2 \times 10^{-3}$, $25 \quad \mathrm{HCO}_{3} / \mathrm{Na}=0.3 \pm 0.3$ and ${ }^{87} \mathrm{Sr} /{ }^{86} \mathrm{Sr}=0.7081 \pm 0.0005$.

The $\mathrm{Sr}$ isotope ratio plotted vs. the molar $\mathrm{Ca} / \mathrm{Sr}$ ratio in Fig. $4 \mathrm{a}$ demonstrates the mixing in Vuojatätno between old silicate rock, with ${ }^{87} \mathrm{Sr} /{ }^{86} \mathrm{Sr}$ ratios $>0.73$ and carbonates (limestone), with ${ }^{87} \mathrm{Sr} /{ }^{86} \mathrm{Sr}$ ratios around 0.709 , also the present value in oceans (Dickin, 1997). Valtajåkka is draining the old granitic Precambrian basement resulting
HESSD

4, 555-588, 2007

\section{Weathering rates and origin of inorganic carbon}

J. Brink et al.

\section{Title Page}

Abstract Introduction

Conclusions

Tables

References

Figures

14

$\rightarrow$

4

Back

Close

Full Screen / Esc

Printer-friendly Version

Interactive Discussion 
in higher $\mathrm{Sr}$ isotope ratios $>0.74$ (Faure, 1986). Vuojatätno also shows very homogenous Sr-isotope ratios over the year, which is probably due to an increasing weathering intensity of isotopic homogenous bedrock and soil layers with increasing discharge but is also influenced by two major lakes upstream of the outlet of Voujatätno in the 5 Akkajaure reservoir, Virihaure $\left(4.4 \mathrm{~km}^{3}\right)$ and Vastenjaure $\left(3.0 \mathrm{~km}^{3}\right)$. In Valtajåkka the $\mathrm{Sr}$ isotope ratios varies with discharge, although the variation is small. The highest $\mathrm{Sr}$ isotope ratio is observed during winter, possibly showing a combination of deeper groundwater percolation near the old Precambrian basement, with higher Sr-isotope values and small dilution effects of the bedrock strontium signal due to low rain water o discharge during winter.

In Table 6 the element mass budgets, weathering rates and the consumed $\mathrm{CO}_{2}$ for the investigated different sources are presented, i.e. carbonates, silicates, evaporites and rain, and atmosphere, silicate and carbonate, respectively. The silicate weathering rate is specified as a flux (mass budget/total drainage basin) and spe15 cific fluxes (mass budget/silicate outcrop in the drainage basin) and the specific weathering of lowland areas (total river load-headwater load)/(total catchment areaheadwater area). The different flux estimates show that cations released from weathering of silicates and the amount of carbon dioxide used for silicate weathering dominates unregulated lowland rivers such as Muddus River (unregulated tributary to Lule River) and the river mouth of Kalix and Kaitum Rivers in the headwater of Kalix River. The silicate weathering rates for these rivers showed almost the same value; $45.1 \times 10^{3} \mathrm{~mol} \mathrm{~km}^{-2} \mathrm{yr}^{-1}$ for Muddus River, $46.7 \times 10^{3} \mathrm{~mol} \mathrm{~km}^{-2} \mathrm{yr}^{-1}$ for Killingi and $47.4 \times 10^{3} \mathrm{~mol} \mathrm{~km}^{-2} \mathrm{yr}^{-1}$ for the river mouth of Kalix River. At the river mouth of Lule River this value is $27.7 \times 10^{3} \mathrm{~mol} \mathrm{~km}^{-2} \mathrm{yr}^{-1}$. In the headwaters of Lule River these 25 numbers are, Valtajåkka $27.9 \times 10^{3} \mathrm{~mol} \mathrm{~km}^{-2} \mathrm{yr}^{-1}$, Vuojatätno $24.7 \times 10^{3} \mathrm{~mol} \mathrm{~km}^{-2} \mathrm{yr}^{-1}$, Akkajaure $26.0 \times 10^{3} \mathrm{~mol} \mathrm{~km}^{-2} \mathrm{yr}^{-1}$ and Sitas $16.4 \times 10^{3} \mathrm{~mol} \mathrm{~km}^{-2} \mathrm{yr}^{-1}$ showing the slowest silicate weathering rate (Table $6, F_{\text {cationic }}$ sil). To get a more "true" value for the silicate weathering rate, it is possible to relate the rate to the specific outcrop of silicate rock in the drainage area. Here presented as $F_{\text {cationic }}$ sil specific outcrop (mol/specific
HESSD

$4,555-588,2007$

\section{Weathering rates and origin of inorganic carbon}

J. Brink et al.

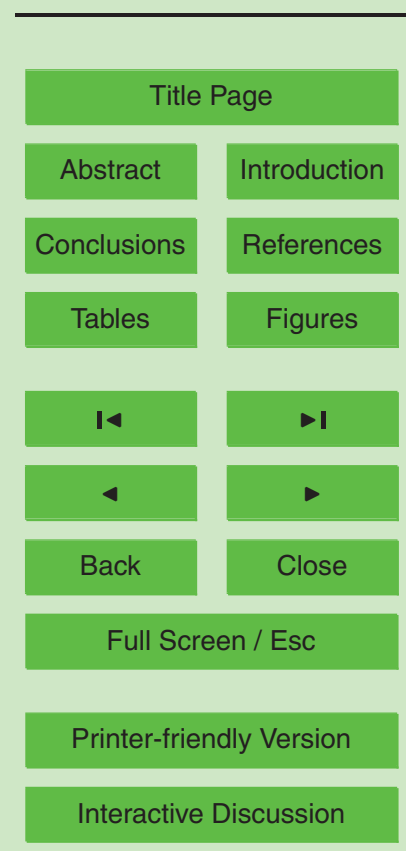

EGU 
outcrop of silicate rock in $\mathrm{km}^{2} / \mathrm{year}$ ). The calculated specific cationic silicate denudation rates, $F_{\text {cationic }}$ sil specific outcrop, for Vuojatätno, Valtajåkka, Lule River mouth, and Sitas are; $38.0 \times, 35.4 \times, 32.1 \times$, and $22.9 \times 10^{3} \mathrm{~mol} \mathrm{~km}^{-2} \mathrm{yr}^{-1}$, respectively.

\section{Discussion}

5 On a large scale many variables control the chemical denudation of continents, such as lithology, runoff, temperature, relief and vegetation. The importance of bedrock on chemical denudation rates was identified early (Garrels and Mackenzie, 1971; Meybeck, 1987). Studies have shown that the silicate chemical weathering rates are 2 to 3 times higher for silicate rocks in the Andean mountain basins compared to the lowland basins (Gaillardet et al., 1997). The largest difference of almost a factor 40 is shown for the River Solimoes, draining the Andes, compared to the Rio Negro (Guayana shield, highly weathered Precambrian shield) in the lowland. In another study on the 60 largest rivers of the world, Gaillardet et al. (1999) concluded that the possible controlling variables for modern silicate weathering rates is a combined effect of runoff-temperature and physical denudation. These parameters which are related to both climate (e.g., temperature, precipitation, and runoff) and tectonics (e.g., physical denudation, sediment transport, landscape surface age, and bedrock exhumation) are the main principal factors controlling physical and chemical weathering over geological time scale (i.e. transport-limited or weathering-limited regime). Recent studies have also shown the importance of DOC/TOC (Humborg et al., 2004; Millot et al., 2003) for Si concentration in rivers and thereby silicate weathering rates.

Our detailed analyses on weathering rates in boreal and sub arctic systems shows that although much higher specific discharge and steeper slope angel, i.e. higher physical erosion, the weathering rates are less in a regulated river compared to an unregulated river, i.e., lower concentrations of dissolved solids can not only be explained by a dilution effect; there is indeed less weathering occurring. Moreover, weathering rates are higher in the lowlands compared to the headwaters in both systems. This suggest
HESSD

4, 555-588, 2007

\section{Weathering rates and origin of inorganic carbon \\ J. Brink et al.}

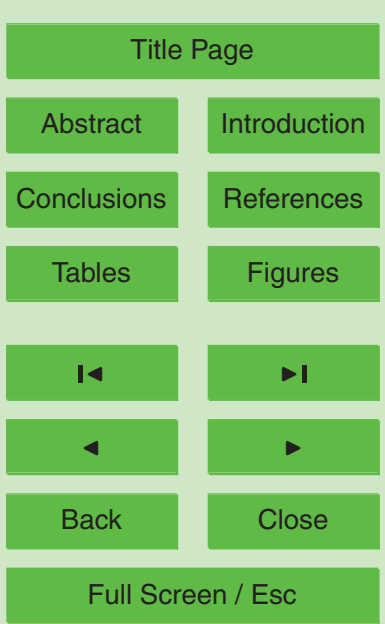

Printer-friendly Version

Interactive Discussion 
that in this cold and weathering limited system the role of vegetation and soil thickness is much more evident for weathering rates than in warmer and wetter climates elsewhere. However, about $5 \%$ of the total land cover within the watershed of the Lule River has been converted into water area (reservoirs) and this occurred especially 5 along the river valleys of the headwaters where alluvial sediment was continuously deposited leading to a formerly riparian zone with a rich vegetation cover. The effect of this \% change in land cover is therefore much higher than what is revealed with number on how much land is converted into water area. Although we can not quantify yet the role of these alluvial deposits for overall weathering rates we hypothesize

10 here that the drowning of these areas that came along with river regulation explain to a significant extent the lower weathering rates observed in the Lule River compared to the Kalix River. The effect from much smaller water level fluctuations in the river valley not affected by damming should also be considered as an important factor (reduced water/soil interactions in the riparian zone).

\subsection{Weathering sources, major dissolved components, TOC and end member mixing}

The silicate dominated Precambrian basement in the lowland of the Kalix and Lule River shifts the river mouths chemistry more toward the Si corner in the ternary diagram (Fig. 3), compared to the more carbonate dominated headwaters (especially Vuojatätno and Sitas which represent catchments with large lakes). This silicate weathering signal is also observed in the mixing diagram for Muddus River, Kaitum River (Killingi) and Valtajåkka (Fig. 4), where the sodium normalized values are lower than the tributaries to the Akka system with carbonate weathering dominance.

In the pristine catchment Kalix River, and in the unregulated Valtajåkka and Muddus River in Lule River Basin, the major element concentrations vary seasonally (Table 5). 25 Vuojatätno, Sitas and the river mouth of Lule River show very small dilution effects (i.e. melt water diluting the ground water signal), which probably can be attributed to the lithology in Vuojatätno (and large lakes upstream) and regulation effects for Sitas and Lule River (large reservoirs). The seasonality, with spring peak discharge and
HESSD

$4,555-588,2007$

\section{Weathering rates and origin of inorganic carbon \\ J. Brink et al.}

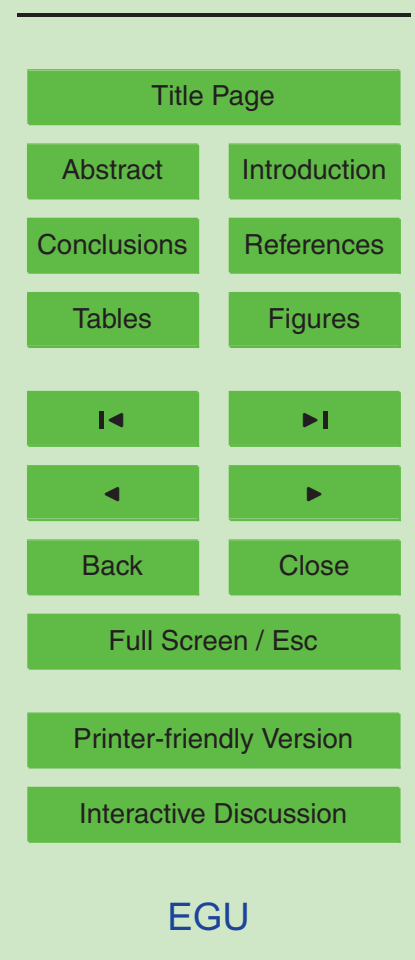


low winter base flow is flattened out on yearly basis compared to the Kalix River, as well as the differences in concentration of major element. Vuojatätno is dominated by carbonate rock weathering (see Figs. 3 and 4), which under high discharge may lead to an increase in weathering (Berner and Berner, 1996). The same effect may also 5 be important for the weathering of silicates, when fresh silicate mineral surfaces are exposed to the increasing physical erosion caused by high runoff (but only to a certain degree where dilution may become important again).

This inverse relationship between $\mathrm{Ca}^{2+}$ and $\mathrm{Na}^{+}$, is unusual in fresh waters, and may be a result of dominating rainwater contribution to stream water (sea salt), halite 10 dissolution, silicate dominating weathering (Na-plagioclase) over Calcite, or biomass uptake of $\mathrm{Ca}^{2+}$. In small river catchments it can be difficult to quantify the mean annual concentrations when studies have been done with only a few samples. Short-term climatic and biotic fluctuations can be omitted or in some cases dominate the data, principally due to the role of flood events in small watersheds. Salt and nutrients are stored in the unsaturated zones and washed out during events of high discharge (Drever, 1997). Each flood influences significantly the annual mass balance of elements and discharge and can be hard to capture in small watersheds with a fast response to rainfall/snowmelt and thereby showing large fluctuations in runoff during the year.

In Vuojatätno where carbonate sedimentary rocks are present, the $\mathrm{Ca}^{2+}$ concentration exceeds $100 \mu \mathrm{mol} \mathrm{L}{ }^{-1}$ and alkalinity (as $\mathrm{HCO}_{3}^{-}$) reaches values around $200 \mu \mathrm{eq}$ $\mathrm{L}^{-1}$. The highest dissolved Si concentration in the headwater of Lule River was observed in Valtajåkka as shown by Humborg et al. (2004) to be caused by vegetated soil (in Valtajåkka the land cover consists of $1.13 \%$ coniferous forest, mainly spruce and $13.62 \%$ deciduous forest, mainly birch), and it is very likely that vegetation plays 25

an important role for weathering of silicates (Moulton and Berner, 1998; Moulton et al., 2000), especially in a weathering rate limited environment (Anderson et al., 2000; Drever, 1994; Drever and Zobrist, 1992; Millot et al., 2002). Jacobson et al. (2003) stress the importance of geomorphic control on silicate weathering in the Southern Alps, New Zealand, which support our result of silicate weathering rates (Table 7) from

HESSD

4, 555-588, 2007

\section{Weathering rates and origin of inorganic carbon}

J. Brink et al.

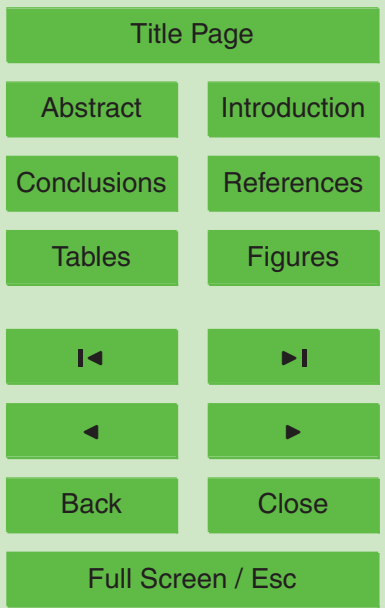

Printer-friendly Version

Interactive Discussion 
the headwater of Lule and Kalix River. In these weathering limited regimes, with steep topography, rapid discharges (short mean residence times for water), and small vegetated flood plains, water-rock interaction times are limited. Under these conditions, chemical weathering is selective and favours highly soluble minerals with rapid disso5 lution rates like calcite instead of silicate minerals. The low silicate weathering rates in the uppermost part of the headwater of Kalix River and Lule River, can therefore be explained by this geomorphic/water-rock interaction theory.

\subsection{Weathering rates}

The calculated weathering rates for the investigated rivers show higher rates for the Kalix River system compared to the Lule River system (Table 6). Furthermore, the silicate weathering rate is the highest in the lowland part, with rates of $48 \times 10^{3} \mathrm{~mol} \mathrm{~km}^{-2} \mathrm{yr}^{-1}$ and $45 \times 10^{3} \mathrm{~mol} \mathrm{~km}^{-2} \mathrm{yr}^{-1}$, in the Kalix and Lule River respectively. In the headwaters these numbers are $47 \times 10^{3} \mathrm{~mol} \mathrm{~km}^{-2} \mathrm{yr}^{-1}$ calculated for Killingi in the Kalix River basin and $38 \times 10^{3} \mathrm{~mol} \mathrm{~km}^{-2} \mathrm{yr}^{-1}$ calculated for Vuojatätno, in the Lule

15 River Basin. This difference in rates suggests that silicate weathering in sub-arctic boreal climates is controlled by the residence time for water rock interactions followed by lithology. Dam constructions have shown to be a sink for nutrients, due to the increase of water residence time, which produces the pre condition for photosynthesis and algal growth in the reservoirs (Humborg et al., 2000, 1997). Previous studies have, however, 20 concluded that biological uptake of dissolved Si by diatoms is not significant in the Lule River basin and it can therefore be ruled out that this is a major sink for Si (Humborg et al., 2004).

In the headwater, were we have steep topography and higher runoff like in Vuojatätno the lithology is of major importance, given the highest silicate weathering rate 25 for Vuojatätno, were we have more weatherable minerals compared to the other headwater rivers at the same altitude and with similar runoff. Killingi in Kaitum river is draining an area in size comparable to Vuojatätno's with a similar landscape cover, i.e. glacier, barren land, unvegetated and vegetated soil, but is reaching to a lower ele-

HESSD

4, 555-588, 2007

\section{Weathering rates and origin of inorganic carbon}

J. Brink et al.

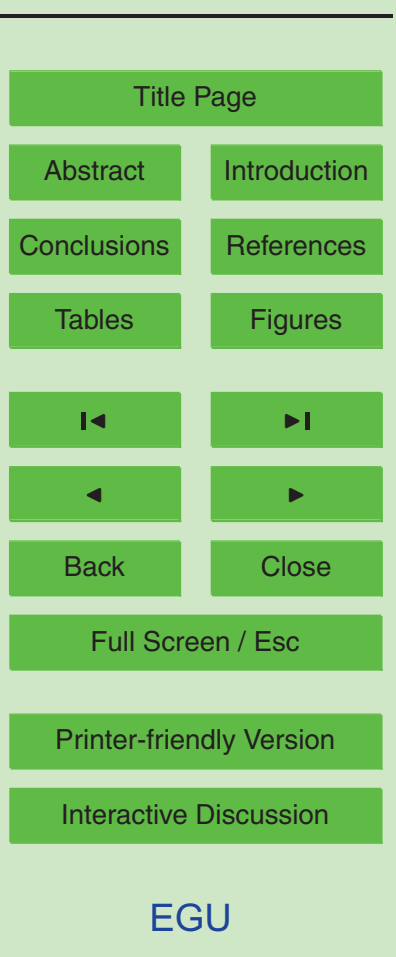


vation (from about 400-2000 m a.s.I.) compared to Vuojatätno, where more vegetated soils increase water rock interaction time, making the weathering less selective and optimizing weathering of silicates compared to highly soluble calcite.

This study and the study of the sub-arctic Mackenzie River basin by Millot et 5 al. (2003), reports (in comparison with the global average river) low silicate weathering rates. The silicate fluxes (as cationic silicate weathering rates) calculated for Lule River Basin and Kalix River Basin, range from 0.92 to $1.61 \mathrm{tkm}^{-2} \mathrm{yr}^{-1}$, respectively, and for Mackenzie River basin from 0.13 to $4.33 \mathrm{t} \mathrm{km}^{-2} \mathrm{yr}^{-1}$. Land and Ohlander (2000) have estimate the chemical weathering rates (as base cation flux) of granitic till 10 in a small catchment $\left(9.4 \mathrm{~km}^{2}\right)$ in Kalix River Basin to $0.356-0.553 \mathrm{keq} \mathrm{ha}^{-1} \mathrm{yr}^{-1}$, which is slightly lower than our estimation for Lule River and Kalix River basin of 0.415 and $0.727 \mathrm{keq} \mathrm{ha}^{-1} \mathrm{yr}^{-1}$, respectively.

The difference in weathering rates for Kalix and Lule River is most likely caused by the inundations of the river valleys in Lule River in order to regulate the water (build-

\section{3 $\mathrm{CO}_{2}$ consumption (sequestration of $\mathrm{C}$ ) and weathering rates}

Globally about $64 \%$ (or near 2/3) of the dissolved inorganic carbon (DIC, mainly as $\mathrm{HCO}_{3}^{-}$) in natural waters is derived from the reaction between carbonic acid and minerals (Berner and Berner, 1996; Meybeck, 1987). The production of $\mathrm{HCO}_{3}^{-}$is a result of

the consumption/sequestration of atmospheric/soil $\mathrm{CO}_{2}$ during weathering of silicate and carbonate rocks (Reactions 3-6). The relative distribution between silicate and carbonate rock origin of DIC varies, largely because of the much higher weathering rates for the dissolution of carbonate rocks. The contribution of silicate rock in DIC

HESSD

4, 555-588, 2007

\section{Weathering rates and origin of inorganic carbon \\ J. Brink et al.}

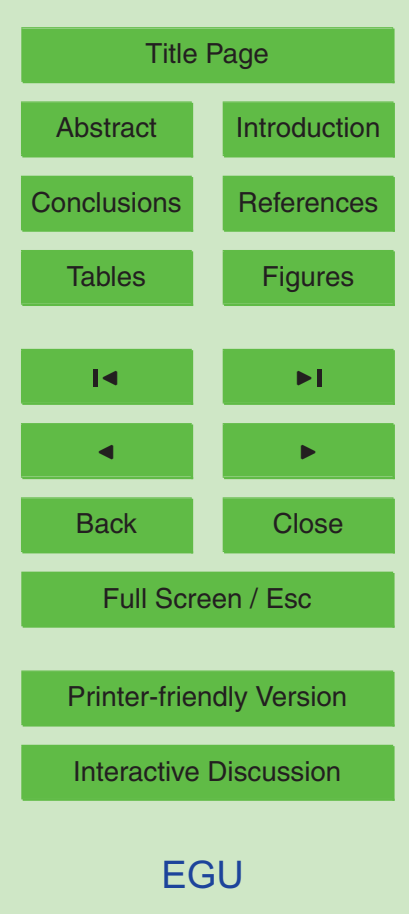


is from the carbonate rich drainage areas of Sitas and Vuojatätno $57 \%$ and $55 \%$, respectively, and for the silicate dominated drainage areas of Valtajåkka $63 \%$, Muddus River $82 \%$, river mouth of Lule River $68 \%$, headwater of Kalix River $72 \%$ and at river mouth of Kalix River $74 \%$ (Table 6 ). The total alkalinity calculated from the stoichiome5 try with the used model in this study overestimates the alkalinity with nearly 20 to $30 \%$, showing that other proton sources than carbonic acid may be important, i.e. for example pyrite weathering and DOC. The $\mathrm{CO}_{2}$ consumption/sequestration estimated during weathering are in this study based on the assumption that the only proton source for rock weathering is carbonic acid.

10 The organic transport of carbon to the sea includes also most of the inorganic carbon since a large part of the inorganic carbon originates from degradation of organic matter, i.e. from soil respiration. For the Kalix River (1990-2000) the mean for TOC (expressed as C) was $4.9 \mathrm{mg} \mathrm{L}^{-1}$ and for Lule River (1990-2000) $2.4 \mathrm{mg} \mathrm{L}^{-1}$ (Nilsson, 2006). Taking the alkalinity value as approximately the bicarbonate concentration (and

all inorganic carbon, this assumption will underestimate the inorganic carbon) the inorganic $C$ that originates from organic $C$ is for the Kalix River $1.9 \mathrm{mg} \mathrm{L}^{-1}$ (from Table 5, $0.216 \times 12 \times 0.74$ ) and for Lule River $1.2 \mathrm{mg} \mathrm{L}^{-1}$ (from Table $5,0.149 \times 12 \times 0.68$ ). This means that the organic carbon load for Kalix River is underestimated by $30 \%$ and for Lule River by almost $35 \%$. This shows that if climate effects are investigated and only 20 using TOC/DOC as a proxy for increased degradation of organic matter changes in the total carbon load may occur but not necessarily detected in the TOC/DOC fraction (i.e. leads to more weathering and production of more DIC). The total carbon load, inorganic and organic, must therefore be considered if trends for carbon balances in boreal sub arctic watersheds are investigated. In conclusion not only dissolved solids as $\mathrm{Si}, \mathrm{Ca}$ and $\mathrm{Mg}$ will decrease with regulation (Humborg et al., 2000, 1997), a destruction of soil layers due to damming or erosion will decrease alkalinity export fluxes and therefore also influence regional $\mathrm{C}$ budgets.
HESSD

4, 555-588, 2007

\section{Weathering rates and origin of inorganic carbon \\ J. Brink et al.}

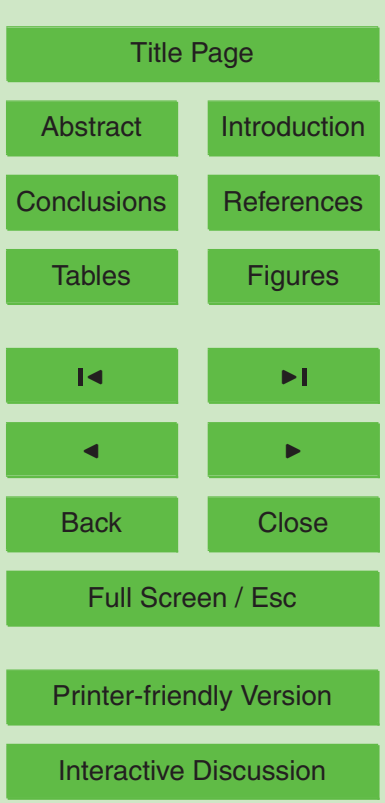

EGU 


\section{Conclusions}

The difference in chemical weathering rates between lowland regions and headwaters suggests that silicate weathering in sub arctic boreal climates is controlled by the residence time for soil water rock interactions followed by lithology.

5 The calculated weathering rates for the investigated rivers show higher rates for the Kalix River system compared to the Lule River system by $30 \%$. The difference in weathering rates for Kalix and Lule River is most likely caused by the inundations of the river valleys in Lule River where the alluvial deposits are "drowned" in the reservoirs causing water to have shorter residence in soils/rocks (see above on the importance of residence time vs. lithology).

The contribution in DIC from weathering of silicate rocks (sequestration of C), i.e. silicate origin of DIC, varies from $55 \%$ in the carbonate rich basins to about $80 \%$ in basins with high silicate rock domination. At river mouth these numbers are; Lule River, $68 \%$ and Kalix River, $74 \%$. The actual organic carbon load leaving these rivers is therefore higher, since the carbon in DIC generated by weathering of silicate rocks origins from degradation of organic matter in soils. This means that the organic carbon load for Kalix River is underestimated by $30 \%$ and for Lule River by almost $35 \%$. If climate effects are investigated and only using TOC/DOC as a proxy for increased degradation of organic matter, changes in the total carbon load may occur, but not necessarily detected in the TOC/DOC fraction. The total carbon load, inorganic and organic, must therefore be considered if trends for carbon balances in boreal sub arctic watersheds are investigated.

\section{References}

Almgren, T., Dyrssen, D., and Fonselius, S.: Determination of alkalinity and total carbonate, in: 25 Methods of Seawater Analysis, edited by: Grasshof, K., Erhardt, M. and Kremling, K., Verlag Chemie, Weinheim, Germany, 99-123, 1983.

\section{HESSD}

4, 555-588, 2007

\section{Weathering rates and origin of inorganic carbon \\ J. Brink et al.}

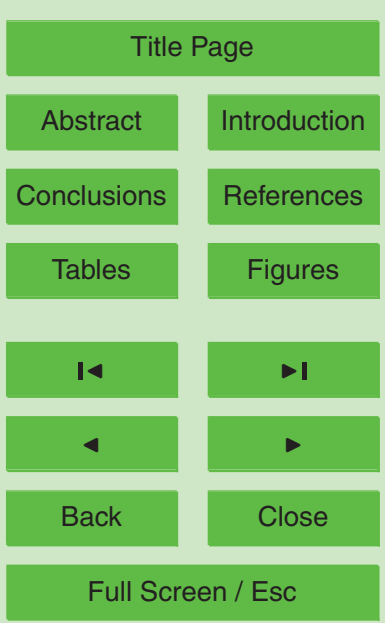

Printer-friendly Version

Interactive Discussion 
Amiotte-Suchet, P. and Probst, J. L.: Modelling of atmospheric $\mathrm{CO}_{2}$ consumption by chemical weathering of rocks: application to the Garonne, Congo and Amazon basins, Chem. Geol., 107, 205-210, 1993.

Amrhein, C. and Suarez, D. L.: The use of a surface complexation model to describe the kinetics of ligand-promoted dissolution of anorthite, Geochimica et Cosmichimica Acta, 52(12), 2785-2793, 1988.

Anderson, S. P., Drever, J. I., Frost, C. D., and Holden, P.: Chemical weathering in the foreland of a retreating glacier, Geochimica et Cosmochimica Acta, 64, 1173-1189, 2000.

Andreasson, P. G. and Gee, D. G.: Baltoscandia's outer margin (the Seve Nappe Complex) in the Kabnekaise-Singis area of Norrbotten, Swedish Caledonides. GFF, 111, 378-381, 1989.

Bergström, S. and Forsman, A.: Development of a conceptual deterministic rainfall-runoff model, Nordic Hydrology, 4, 147-170, 1973.

Berner, E. K. and Berner, R. A.: Global Environment: Water, Air, and Geochemical cycles, Prentice-Hall, 376 pp, 1996.

Berner, R. A., Lasaga, A. C., and Garrels, R. M.: The carbonate silicate geochemical cycle and its effect on atmospheric carbon dioxide over the past 100 millions years, Am. J. Sci., 283, 641-683, 1983.

Björklund, L.: The Middle and Lower Allochthons in the Akkajaure-Tysfjord area, northern Scandinavian Caledonides, in: The Caledonide Orogen-Scandinavia and Related Areas, edited 20 by: Gee, D. G. and Sturt, B. A., John Wiley \& Sons, 512-528, 1985.

Bluth, G. J. S. and Kump, L. R.: Lithological and climatological controls of river chemistry. Geochimica et Cosmochimica Acta, 58, 2341-2359, 1994.

Dickin, A. P.: Radiogenic isotope geology, Cambridge University Press, Cambridge, 1997.

Drever, J. I.: The effect of land plants on weathering rates of silicate minerals, Geochimica et Cosmochimica Acta, 58, 2325-2332, 1994.

Drever, J. I.: The Geochemistry of Natural Waters: Surface and Groundwater Environments, Prentice-Hall, Upper Saddle River, New Jersey, 436 pp, 1997.

Drever, J. I. and Clow, D. W.: Weathering rates in catchments, in: Chemical Weathering Rates of Silicate Minerals: Reviews in Mineralogy, edited by: Brantley, S. and White, A., Mineralogical Society of America, Washington, D.C., 463-483, 1995.

Drever, J. I. and Zobrist, J.: Chemical-weathering of silicate rocks as a function of elevation in the southern Swiss Alps, Geochimica et Cosmochimica Acta, 56, 3209-3216, 1992.

Faure, G.: Principle of Isotope Geology, Wiley, New York, 1986.

HESSD

4, 555-588, 2007

\section{Weathering rates and origin of inorganic carbon}

J. Brink et al.

Title Page

Abstract

Introduction

Conclusions

References

Tables

Figures

14

4

Back

Close

Full Screen / Esc

Printer-friendly Version

Interactive Discussion 
Gaillardet, J., Dupré, B., Allègre, C. J., and Négrel, P.: Chemical and physical denudation in the Amazon River Basin, Chem. Geol., 142, 141-173, 1997.

Gaillardet, J., Dupre, B., Louvat, P., and Allegre, C. J.: Global silicate weathering and CO2 consumption rates deduced from the chemistry of large rivers, Chem. Geol., 159, 3-30, 51999.

Garrels, R. M. and Mackenzie, F. T.: Evolution of Sedimentary Rocks, W. W. Norton \& Company, 397 pp, 1971.

Gee, D. G. and Zachrisson, E.: The Caledonides in Sweden. C769, Sveriges Geologiska Undersökning, 1979.

10 Holland, H. D.: The Chemistry of the Atmosphere and Ocean. John Wiley \& sons, 351 pp, 1978.

Humborg, C., Conley, D. J., Rahm, L., Wulff, F., Cociasu, A., and Ittekkot, V.: Silicon retention in river basins: Far-reaching effects on biogeochemistry and aquatic food webs in coastal marine environments, Ambio, 29(1), 45-50, 2000.

15 Humborg, C., Ittekkot, V., Cociasu, A., and VonBodungen, B.: Effect of Danube River dam on Black Sea biogeochemistry and ecosystem structure, Nature, 386(6623), 385-388, 1997.

Humborg, C., Smedberg, E., Blomqvist, S., et al.: Nutrient variations in boreal and subarctic rivers: Landscape control of land-sea fluxes, Limnol. Oceanogr., 49(5), 1871-1883, 2004.

Jacobson, A. D., Blum, J. D., Chamberlain, C. P., Craw, D., and Koons, P. O.: Climatic and 20 tectonic controls on chemical weathering in the New Zealand Southern Alps, Geochimica Et Cosmochimica Acta, 67(1), 29-46, 2003.

Kulling, O.: The geology of the Caledonian rocks of the northern Norrbotten mountains. 19, Geological Survey of Sweden, Stockholm, Sweden, 1964.

Kulling, O.: The Swedish Caledonides, in: Scandinavian Caledonides, edited by: Strand, T. and Kulling, O., John Wiley \& Sons Ltd, 147-285, 1972.

Kulling, O.: Översikt över norra Norrbottenfjällens kaledonberggrund, 19, Geological Survey of Sweden, Uppsala, Sweden, 1982.

Land, M. and Ohlander, B.: Chemical weathering rates, erosion rates and mobility of major and trace elements in a boreal granitic till, Aquatic Geochem., 6(4), 435-460, 2000.

30 Meybeck, M.: Global chemical weathering of surficial rocks estimated from river dissolved loads, Am. J. Sci., 287, 401-428, 1987.

Millot, R., Gaillardet, J., Dupré, B., and Allègre, C. J.: The global control of silicate weathering rates and coupling with physical erosion: new insights from rivers of the Canadian Shield,

HESSD

4, 555-588, 2007

\section{Weathering rates and origin of inorganic carbon}

J. Brink et al.

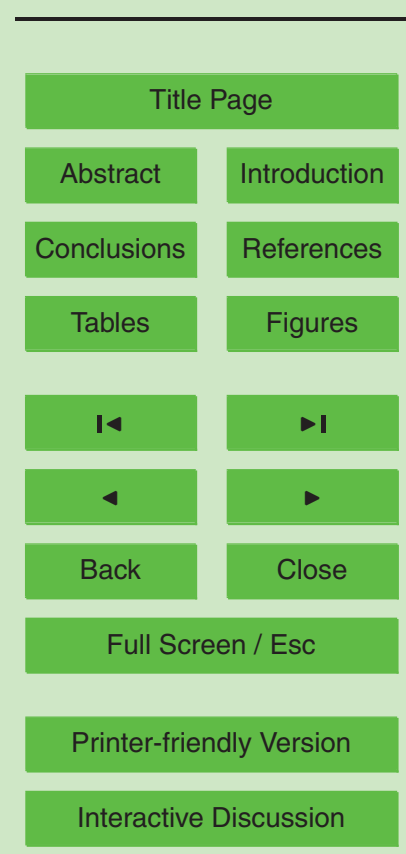

EGU 
Earth Planet. Sci. Lett., 196, 83-98, 2002.

Millot, R., Gaillardet, J., Dupré, B., and Allègre, C. J.: Northern latitude chemical weathering rates: Clues from Mackenzie River Basin, Canada, Geochimica et Cosmochimica Acta, 67(7), 1305-1329, 2003.

5 Mortatti, J. and Probst, J. L.: Silicate rock weathering and atmospheric/soil $\mathrm{CO}_{2}$ uptake in Amazon basin estimated from river water geochemistry: seasonal and spatial variations, Chem. Geol., 1997, 177-196, 2003.

Moulton, K. L. and Berner, R. A.: Quantification of the effect of plants on weathering: Studies in Iceland, Geology, 26(10), 895-898, 1998.

10 Moulton, K. L., West, J., and Berner, R. A.: Solute flux and mineral mass balance approaches to the quantification of plant effects on silicate weathering, Am. J. Sci., 300, 539-570, 2000.

Nilsson, J.: Hydrogeokemin i Kalixälvens, Råneälvens och Luleälvens avrinningsområden, Stockholm University, Stockholm, 52 pp, 2006.

Probst, J. L., Mortatti, J., and Tardy, Y.: Carbon river fluxes and global weathering CO2 consumption in the congo and Amazon river basin, Appl. Geochem., 9, 1-13, 1994.

Raymond, P. A. and Cole, J. J.: Increase in the Export of Alkalinity from North America's Largest River Science, 301, 88-91, 2003.

Sahlberg, J.: Physical control of primary production in a sub-arctic reservoir, Linköping University, Linköping, 2004.

20 White, A. F. and Blum, A. E.: Effects of climate on chemical weathering in watersheds, Geochimica et Cosmochimica Acta, 59, 1729-1747, 1995.

\section{HESSD}

4, 555-588, 2007

\section{Weathering rates and origin of inorganic carbon}

J. Brink et al.

Title Page

Abstract

Introduction

Conclusions

References

Tables

Figures

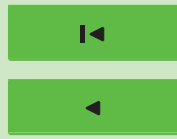

$\rightarrow$

Back

Close

Full Screen / Esc

Printer-friendly Version

Interactive Discussion 


\section{HESSD}

4, 555-588, 2007

Table 1. Hydrology for Lule River and Kalix River and headwater tributaries. The runoff ratio is the ratio of average river runoff (per unit area) to average rainfall (per unit area).

\begin{tabular}{|c|c|c|c|c|c|c|c|c|c|}
\hline & $\begin{array}{l}\text { Lule River } \\
\text { Headwater } \\
\text { Valldajåkka }\end{array}$ & Voujaätno & Sitas & Akkajaure reservoir & $\begin{array}{l}\text { Lowland } \\
\text { Muddusätno }\end{array}$ & River mouth & $\begin{array}{l}\text { Kalix River } \\
\text { Headwater } \\
\text { Inlet to Pajtas }\end{array}$ & Killingi & $\begin{array}{l}\text { Lowland } \\
\text { River mouth }\end{array}$ \\
\hline Catchment $\left(\mathrm{km}^{2}\right)$ & 147 & 2842 & 977 & 4651 & 452 & 25225 & 299 & 2346 & 23846 \\
\hline Mean precipitation (mm) & 1290 & 1332 & 1067 & 1180 & 583 & 698 & 623 & 630 & 544 \\
\hline Men Temperature $\left({ }^{\circ} \mathrm{C}\right)$ & -2 & -2 & -2 & -2 & -1 & 1 & -2 & -1.5 & 1 \\
\hline Mean runoff $\left(\mathrm{m}^{3} \mathrm{~s}^{-1}\right)$ & 5.4 & 109 & 40.0 & 154 & 5.7 & 447 & 4.8 & 38.1 & 296 \\
\hline Specific discharge $\left(\mathrm{L} \mathrm{m}^{-2} \mathrm{yr}^{-1}\right)$ & 1160 & 1208 & 1292 & 1045 & 400 & 559 & 504 & 512 & 391 \\
\hline Runoff Volume $\left({ }^{\star} 10^{12} \mathrm{~L} \mathrm{yr}^{-1}\right)$ & 0.2 & 3.4 & 0.9 & 4.9 & 0.2 & 17.6 & 0.2 & 1.2 & 9.3 \\
\hline$\%$ water discharge to River mouth & 1.1 & 21.5 & 5.9 & 30.4 & 1.0 & 100.0 & 1.6 & 12.9 & 100.0 \\
\hline$\%$ water discharge to Akka system & 3.51 & 70.61 & 19.31 & & & & & & \\
\hline Runoff ratio & 0.90 & 0.91 & 0.90 & 0.89 & 0.69 & 0.80 & 0.81 & 0.81 & 0.72 \\
\hline
\end{tabular}

Lule River:

*Mean precipitation and runoff from the period; 1985 to 2003 for Muddusätno and at river mouth.

*Mean precipitation and runoff from the period; 1998 to 2000 for the headwater area.

Kalix River:

*Mean precipitation and runoff from the period; 1985 to 2003.

Weathering rates and origin of inorganic carbon

J. Brink et al.

Title Page

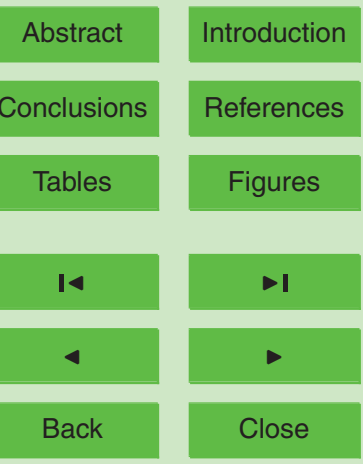

Full Screen / Esc

Printer-friendly Version

Interactive Discussion 


\section{HESSD}

4, 555-588, 2007

Table 2. Element concentration in rainwater.

\begin{tabular}{|c|c|c|c|c|c|c|c|c|c|c|c|c|c|}
\hline River & Location & $\mathrm{pH}$ & $\begin{array}{l}\text { Conductivity } \\
\mu \mathrm{S} \mathrm{cm} \mathrm{cm}^{-1}\end{array}$ & $\begin{array}{l}\mathrm{SO}_{4}^{2-} \\
\mu \mathrm{mol} \mathrm{L}^{-1}\end{array}$ & $\mathrm{Cl}^{-}$ & $\mathrm{NO}_{3}^{-}$ & $\mathrm{NH}_{4}^{+}$ & $\mathrm{H}^{+}$ & $\mathrm{Ca}^{2+}$ & $\mathrm{Mg}^{2+}$ & $\mathrm{Na}^{+}$ & $\mathrm{K}^{+}$ & $\begin{array}{l}\text { CB } \\
\%\end{array}$ \\
\hline \multirow[t]{3}{*}{ Lule } & Headwater & 5.08 & 10.43 & 7.39 & 29.93 & 3.39 & 6.51 & 7.35 & 1.87 & 2.98 & 25.07 & 2.13 & 2.69 \\
\hline & Muddusätno & 4.69 & 12.34 & 13.02 & 5.15 & 12.61 & 12.20 & 21.95 & 2.40 & 1.10 & 4.82 & 2.98 & 5.56 \\
\hline & River mouth & 4.82 & 11.31 & 10.46 & 18.84 & 8.97 & 9.72 & 16.91 & 2.29 & 2.14 & 16.44 & 2.38 & 5.43 \\
\hline \multirow[t]{2}{*}{ Kalix } & Head & 4.92 & 8.0 & 7.42 & 9.50 & 4.32 & 5.71 & 13.40 & 1.27 & 1.10 & 8.08 & 1.00 & 6.92 \\
\hline & River mouth & 4.69 & 12.34 & 13.02 & 5.15 & 12.61 & 12.20 & 21.95 & 2.40 & 1.10 & 4.82 & 2.98 & 5.56 \\
\hline
\end{tabular}

Lule River:

*The element concentrations in Headwater area are mean values from the EMEP station, Trustervatn in Norway, 1977-2003 (http://www.NILU.no), and the PMK stations Abisko and Ammarnäs in Sweden, 1983-2004 (http://www.IVL.se).

*The element concentrations in rainwater for Muddusätno are mean values from the PMK stations, Pålkem in Gällivare district, 1983-2004 (http://www.IVL.se).

${ }^{*}$ The element concentrations in rainwater for River mouth is a weigthted mean value from the PMK stations, Pålkem in Gällivare district and Reivo in Arvidsjaur district (IVL), and the concentration in precipitation from headwater.

Kalix River:

${ }^{*}$ The element concentrations in Headwater area are mean values from the PMK station Abisko in Sweden, 1983-2004 (http://www.IVL.se).

${ }^{*}$ The element concentrations in rainwater for River mouth is mean value from the PMK station, Pålkem in Gällivare district, 1983-2004 (http://www.IVL.se).

\section{Weathering rates and origin of inorganic carbon \\ J. Brink et al. \\ Title Page

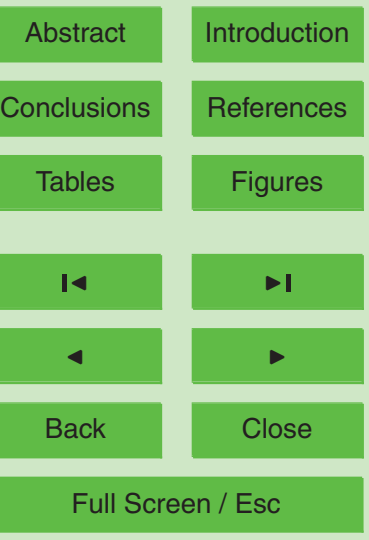

Printer-friendly Version

Interactive Discussion 


\section{HESSD}

4, 555-588, 2007

\section{Weathering rates and origin of inorganic carbon}

Table 3. The areal percent of major bedrock types, and the specific silicate and carbonate outcrop in the investigated catchments.

\begin{tabular}{|c|c|c|c|c|c|c|c|c|c|c|c|c|c|}
\hline \multirow[t]{2}{*}{ River } & & Location & $\begin{array}{l}\text { Carbonate } \\
\text { rock }\end{array}$ & $\begin{array}{l}\text { Carbonate } \\
\text { rich shale }\end{array}$ & Shale & $\begin{array}{l}\text { Basic } \\
\text { Rock }\end{array}$ & Gneiss & $\begin{array}{l}\text { Granite } \\
\text { and acid } \\
\text { volcanic rock }\end{array}$ & Quartzite & Carbonates & $\begin{array}{l}\text { Silicates } \\
\text { outcrop }\end{array}$ & $\begin{array}{l}\text { Silicate } \\
\text { outcrop }\end{array}$ & Carbonate \\
\hline & & & $\%$ & $\%$ & $\%$ & $\%$ & $\%$ & $\%$ & $\%$ & $\%$ & $\%$ & $\mathrm{~km}^{2}$ & $\mathrm{~km}^{2}$ \\
\hline \multirow[t]{6}{*}{ Lule } & Headwater & Vuojatätno & 7.2 & 16.8 & 19.4 & 28.2 & 12.4 & 1.1 & 3.9 & 24.0 & 64.9 & 1843 & 683 \\
\hline & & Valldajåkka & 0.0 & 20.8 & 2.4 & 0.0 & 64.6 & 8.4 & 3.3 & 20.8 & 78.7 & 116 & 31 \\
\hline & & Sitas & 2.0 & 9.1 & 24.9 & 2.0 & 7.9 & 21.8 & 15.1 & 11.1 & 71.7 & 701 & 108 \\
\hline & & Akkajaure reservoir & 4.1 & 13.3 & 17.8 & 16.8 & 25.0 & 3.9 & 4.9 & 17.3 & 68.4 & 3180 & 806 \\
\hline & Lowland & Muddusätno & 0.0 & 0.0 & 0.6 & 21.9 & 0.0 & 77.5 & 0.0 & 0.0 & 77.5 & 450 & 0 \\
\hline & & River mouth & 1.4 & 2.9 & 7.0 & 14.2 & 11.4 & 48.3 & 5.3 & 4.3 & 86.2 & 21749 & 1073 \\
\hline \multirow[t]{3}{*}{ Kalix } & Headwater & Inlet to Pajtas & 0.0 & 0.0 & 0.0 & 37.9 & 39.7 & 14.8 & 7.6 & 0.0 & 100.0 & 299 & 0 \\
\hline & & Killingi & - & - & - & - & - & - & - & - & - & & \\
\hline & Lowland & River mouth & 0.1 & 0.0 & 12.3 & 17.6 & 3.2 & 63.8 & 1.6 & 0.1 & 98.5 & 23488 & 2 \\
\hline
\end{tabular}

Title Page

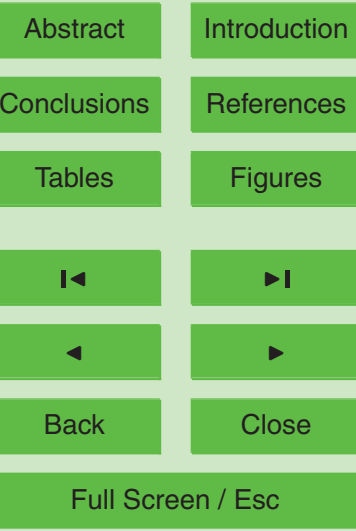

Printer-friendly Version

Interactive Discussion 


\section{HESSD}

4, 555-588, 2007

Table 4. Chemical analyses for Lule River and Kalix River and headwater tributaries. CB refers to the ionic charge balance.

\begin{tabular}{|c|c|c|c|c|c|c|c|c|c|c|c|c|c|c|c|c|c|c|c|c|}
\hline River & & Location & Date & Season & $\mathrm{pH}$ & $\begin{array}{l}\text { Cond } \\
\mu \mathrm{S} \mathrm{cm}^{-1}\end{array}$ & $\begin{array}{l}\text { Alk } \\
\mu \text { eqv } L^{-1}\end{array}$ & $\begin{array}{l}\mathrm{SO}_{4}^{2-} \\
\mu \mathrm{mol} \mathrm{L}^{-1}\end{array}$ & $\mathrm{Cl}^{-}$ & $\mathrm{NO}_{3}+\mathrm{NO}_{2}$ & $\mathrm{NH}_{4}^{+}$ & $\mathrm{Ca}^{2+}$ & $\mathrm{Mg}^{2+}$ & $\mathrm{Na}^{+}$ & $\mathrm{K}^{+}$ & $\mathrm{Si}$ & $\mathrm{Sr}^{2+}$ & $\begin{array}{l}\text { TOC } \\
\mathrm{ppm}\end{array}$ & ${ }^{87} \mathrm{Sr} r^{86} \mathrm{Sr}$ & $\begin{array}{l}\text { CB } \\
\%\end{array}$ \\
\hline \multirow[t]{17}{*}{ Lule } & Headwater & Akkajaure reservoir & 20000614 & Spring & 6.7 & 21.2 & 164.4 & 22.7 & 54.9 & 2.4 & 0.1 & 66.4 & 23.6 & 45.8 & 11.0 & 14.4 & 0.1 & 0.5 & 0.7251 & -6.05 \\
\hline & & & 20000908 & Summer & 6.8 & 19.7 & 134.0 & 20.7 & 53.9 & 1.2 & 0.3 & 64.7 & 23.7 & 45.6 & 10.3 & 14.1 & 0.1 & 0.7 & 0.7233 & 0.52 \\
\hline & & & 20010402 & Winter & $\begin{array}{l}.0 \\
6.8\end{array}$ & 23.4 & 151.8 & 25.0 & 66.0 & 2.5 & 0.5 & 73.2 & 26.5 & 51.1 & 12.1 & 17.2 & 0.1 & 0.6 & 0.7239 & -1.38 \\
\hline & & & & Mean & 6.8 & 21.4 & 150.1 & 22.8 & 58.3 & 2.1 & 0.3 & 68.1 & 24.6 & 47.5 & 11.1 & 15.3 & 0.1 & 0.6 & 0.7241 & -2.36 \\
\hline & & Voujatätno & 20000614 & Spring & 7.0 & 27.8 & 226.0 & 23.5 & 63.8 & 2.3 & 0.1 & 98.2 & 35.4 & 45.1 & 7.2 & 12.7 & 0.2 & 0.4 & 0.7155 & -2.97 \\
\hline & & & 20000908 & Summer & 6.3 & 28.1 & 216.0 & 29.9 & 58.4 & 1.6 & 0.0 & 107.5 & 34.0 & 47.4 & 8.3 & 12.5 & 0.2 & 0.5 & 0.7165 & 0.44 \\
\hline & & & 20010402 & Winter & 6.7 & 35.1 & 227.6 & 28.8 & 69.9 & 3.7 & 0.3 & 111.3 & 37.8 & 47.8 & 12.2 & 15.1 & 0.2 & 0.4 & 0.7159 & -0.03 \\
\hline & & & & Mean & 6.6 & 30.3 & 223.2 & 27.4 & 64.0 & 2.5 & 0.1 & 105.7 & 35.8 & 46.8 & 9.2 & 13.4 & 0.2 & 0.4 & 0.7160 & -0.82 \\
\hline & & Valldajåkka & 20000614 & Spring & 6.7 & 11.3 & 52.1 & 10.6 & 48.7 & 1.0 & 0.1 & 21.6 & 13.8 & 43.6 & 5.5 & 11.8 & 0.0 & 0.7 & 0.7402 & -1.36 \\
\hline & & & 20000908 & Summer & 6.2 & 10.4 & 48.3 & 14.1 & 47.1 & 0.0 & 0.0 & 30.0 & 15.8 & 39.4 & 5.8 & 17.0 & 0.0 & 1.4 & 0.7441 & 5.16 \\
\hline & & & 20010402 & Winter & 7.0 & 23.5 & 120.6 & 24.6 & 71.7 & 3.6 & 0.2 & 60.5 & 26.7 & 70.7 & 28.7 & 70.7 & 0.1 & 0.5 & 0.7467 & 5.58 \\
\hline & & & & Mean & 6.7 & 15.1 & 73.7 & 16.4 & 55.8 & 1.6 & 0.1 & 37.4 & 18.8 & 51.2 & 13.3 & 33.2 & 0.1 & 0.9 & 0.7437 & 3.83 \\
\hline & & Sitas & 20000614 & Spring & 6.5 & 19.0 & 138.7 & 23.2 & 55.2 & 2.5 & 0.2 & 59.8 & 20.2 & 44.1 & 11.8 & 13.5 & 0.1 & 0.5 & 0.7314 & -5.84 \\
\hline & & & 20000908 & Summer & 7.1 & 17.1 & 107.5 & 23.5 & 46.5 & 1.5 & 0.0 & 58.0 & 17.3 & 39.2 & 10.9 & 11.7 & 0.1 & 0.4 & 0.7316 & -0.43 \\
\hline & & & & Mean & 6.8 & 18.1 & 123.1 & 23.3 & 50.8 & 2.0 & 0.1 & 58.9 & 18.7 & 41.6 & 11.4 & 12.6 & 0.1 & 0.5 & 0.7315 & -3.1 \\
\hline & Lowland & Muddusätno & $1985-2003$ & & 7.0 & & 201.1 & 19.5 & 20.5 & 3.5 & 1.8 & 87.9 & 30.8 & 61.9 & 11.6 & 113.9 & & 5.5 & & \\
\hline & & River mouth & $1985-2003$ & & 6.9 & 29.3 & 149.2 & 22.1 & 48.0 & 2.1 & 1.1 & 70.6 & 27.9 & 61.3 & 11.2 & 40.1 & & 2.8 & & 5.28 \\
\hline \multirow{8}{*}{ Kalix } & Headwater & inlet to Pajtas & 19990425 & Winter & & 30. & & & & 2. & 0.2 & 81.3 & 9.9 & 27.0 & 38.8 & 92.9 & 0.1 & & & \\
\hline & & & 19991208 & Winter & & 31.3 & 136.6 & 41.5 & 19.6 & 3.2 & 0.3 & 69.2 & 8.2 & 22.7 & 37.0 & 93.4 & 0.1 & & & -6.12 \\
\hline & & & 20000508 & Winter & & & & 52 & 31.6 & 1.2 & 0.2 & 69.7 & 11.8 & 27.2 & 29.4 & 90.1 & 0.1 & & & \\
\hline & & & 20000818 & Summer & 6.9 & 11.0 & 88.4 & 20.1 & 15.1 & 0.2 & 0.1 & 43.9 & 4.1 & 13.3 & 17.5 & 42.9 & 0.1 & 0.9 & 0.74229 & -6.28 \\
\hline & & & 20010404 & Winter & 6.3 & 23.3 & 146.0 & 42.0 & 19.1 & 5.8 & 0.2 & 81.8 & 9.6 & 27.3 & 35.5 & 110.9 & 0.1 & 0.5 & 0.752553 & -1.87 \\
\hline & & & & Mean & 6.6 & 23.9 & 123.7 & 38.9 & 21.3 & 2.5 & 0.2 & 69.2 & 8.7 & 23.5 & 31.6 & 86.0 & 0.1 & 0.7 & 0.74742 & -3.30 \\
\hline & & Killingi & 1985-2003 & & 6.8 & & 223.9 & 37.6 & 14.6 & 3.3 & 1.6 & 102.7 & 36.7 & 59.0 & 12.6 & 78.6 & & 2.1 & & 5.02 \\
\hline & Lowland & River mouth & $1985-2003$ & & 6.8 & & 216.1 & 51.1 & 45.9 & 6.9 & 2.5 & 112.1 & 47.5 & 84.9 & 16.6 & 100.3 & & 5.1 & & 6.27 \\
\hline
\end{tabular}

\section{Weathering rates and origin of inorganic carbon}

J. Brink et al.

Title Page

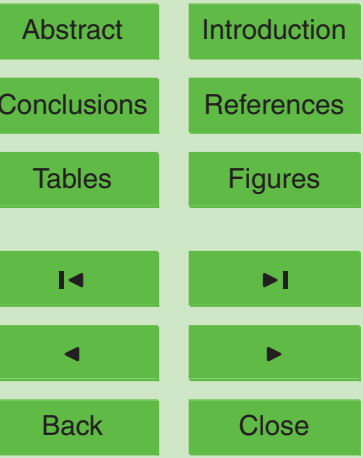

Full Screen / Esc

*The concentrations are not corrected for atmospheric inputs (see Table 2 for mean rainwater

\section{Fil} concentrations)

${ }^{*} \mathrm{CB}=\left(\left(\sum\right.\right.$ cations $-\Sigma$ anions $) /\left(\sum\right.$ cations $+\sum$ anions $\left.)\right){ }^{*} 100$

Printer-friendly Version

Interactive Discussion 
Table 5. Calculations for each reservoirs element budget $(\mu \mathrm{mol})$ and their contributions in percent. The silicate flux $\mathrm{F}$ (as cationic) is presented as ${ }^{*} 10^{3} \mathrm{~mol} \mathrm{~km}^{-2} \mathrm{yr}^{-1}$. The percent for the $\mathrm{CO}_{2}$ atm $\left(\mathrm{CO}_{2}\right.$ used for rock weathering of silicates and carbonates), $\mathrm{CO}_{2}$ carb $\left(\mathrm{CO}_{2}\right.$ used for carbonate weathering) and $\mathrm{CO}_{2}$ sil $\left(\mathrm{CO}_{2}\right.$ used for silicate weathering).

\begin{tabular}{|c|c|c|c|c|c|c|c|c|c|c|c|c|c|c|c|c|c|c|}
\hline Budgets & $\begin{array}{l}\text { Lule River } \\
\text { Headwater } \\
\text { Vuojatätno } \\
\mu \text { mol }\end{array}$ & $\%$ & Valldajåkka & $\%$ & Sitas & $\%$ & Akkajaure reservoir & $\%$ & $\begin{array}{l}\text { Lowland } \\
\text { Muddus }\end{array}$ & $\%$ & River mouth & $\%$ & $\begin{array}{l}\text { Kalix River } \\
\text { Headwater } \\
\text { Inlet to Pajtas }\end{array}$ & $\%$ & Killingi & $\%$ & $\begin{array}{l}\text { Lowland } \\
\text { River mouth }\end{array}$ & $\%$ \\
\hline $\mathrm{Ca}^{2+}$ sil & $1.84 \mathrm{E}+13$ & 5 & $1.02 \mathrm{E}+12$ & 15 & $3.06 \mathrm{E}+12$ & 5.2 & $3.44 \mathrm{E}+13$ & 10 & $8.29 \mathrm{E}+12$ & 52 & $2.52 E+14$ & 25 & $3.60 E+12$ & 32 & $4.17 \mathrm{E}+13$ & 34 & $4.34 \mathrm{E}+14$ & 38 \\
\hline $\mathrm{Ca}^{2+}$ carb & $3.13 E+14$ & 92 & $5.54 \mathrm{E}+12$ & 80 & $5.35 E+13$ & 91 & $2.96 \mathrm{E}+14$ & 87 & $6.98 \mathrm{E}+12$ & 44 & $7.03 E+14$ & 71 & $7.19 E+12$ & 65 & $7.99 E+13$ & 65 & $6.71 E+14$ & 59 \\
\hline $\mathrm{Ca}^{2+}$ rain & $7.08 \mathrm{E}+12$ & 2 & $3.55 \mathrm{E}+11$ & 5 & $1.95 E+12$ & 3 & $1.03 E+13$ & 3 & $6.33 E+11$ & 4 & $4.04 E+13$ & 4 & $3.11 \mathrm{E}+11$ & 3 & $1.82 \mathrm{E}+12$ & 1 & $3.11 \mathrm{E}+13$ & 3 \\
\hline $\mathrm{Mg}^{2+}$ sil & $7.16 \mathrm{E}+12$ & 6 & $3.95 E+11$ & 11 & $1.19 \mathrm{E}+12$ & 7 & $1.34 E+13$ & 11 & $3.22 \mathrm{E}+12$ & 58 & $9.82 E+13$ & 25 & $1.40 E+12$ & 37 & $1.62 E+13$ & 37 & $1.69 \mathrm{E}+14$ & 37 \\
\hline $\mathrm{Mg}^{2+}$ carb & $9.89 \mathrm{E}+13$ & 84 & $2.53 E+12$ & 72 & $1.35 E+13$ & 76 & $8.79 E+13$ & 75 & $2.06 \mathrm{E}+12$ & 37 & $2.58 \mathrm{E}+14$ & 66 & $2.11 \mathrm{E}+12$ & 56 & $2.64 E+13$ & 60 & $2.77 E+14$ & 60 \\
\hline $\mathrm{Mg}^{2+}$ rain & $1.13 \mathrm{E}+13$ & 10 & $5.65 \mathrm{E}+11$ & 16 & $3.11 \mathrm{E}+12$ & 18 & $1.64 \mathrm{E}+13$ & 14 & $2.90 \mathrm{E}+11$ & 5 & $3.77 E+13$ & 10 & $2.87 E+11$ & 8 & $1.48 \mathrm{E}+12$ & 3 & $1.43 \mathrm{E}+13$ & 3 \\
\hline $\mathrm{K}^{+}$sil & $2.77 \mathrm{E}+13$ & 77 & $1.76 \mathrm{E}+12$ & 81 & $9.04 \mathrm{E}+12$ & 80 & $4.16 \mathrm{E}+13$ & 78 & $1.31 \mathrm{E}+12$ & 63 & 1.17E+14 & 74 & $1.19 E+12$ & 84 & $1.38 \mathrm{E}+13$ & 91 & $1.32 \mathrm{E}+14$ & 78 \\
\hline $\mathrm{K}^{+}$rain & $8.06 \mathrm{E}+12$ & 23 & $4.04 \mathrm{E}+11$ & 19 & $2.22 \mathrm{E}+12$ & 20 & $1.17 \mathrm{E}+13$ & 22 & $7.84 \mathrm{E}+11$ & 37 & $4.18 \mathrm{E}+13$ & 26 & $2.24 \mathrm{E}+11$ & 16 & $1.42 \mathrm{E}+12$ & 9 & $3.84 \mathrm{E}+13$ & 22 \\
\hline $\mathrm{Na}^{+}$sil & $1.68 \mathrm{E}+13$ & 10 & $9.28 \mathrm{E}+11$ & 11 & $2.79 \mathrm{E}+12$ & 7 & $3.14 E+13$ & 15 & $7.56 \mathrm{E}+12$ & 68 & $2.30 E+14$ & 27 & $3.28 \mathrm{E}+12$ & 54 & $3.80 E+13$ & 54 & $3.96 \mathrm{E}+14$ & 45 \\
\hline $\mathrm{Na}^{+}$rain & $9.49 \mathrm{E}+13$ & 56 & $4.76 \mathrm{E}+12$ & 57 & $2.62 E+13$ & 66 & $1.38 \mathrm{E}+14$ & 67 & $1.27 \mathrm{E}+12$ & 11 & $2.89 \mathrm{E}+14$ & 33 & $\begin{array}{l}2.37 E+12 \\
2.72\end{array}$ & $\begin{array}{l}39 \\
39\end{array}$ & $1.16 \mathrm{E}+13$ & 16 & $6.23 \mathrm{E}+13$ & 7 \\
\hline $\mathrm{Na}^{+}$eva & $5.89 \mathrm{E}+13$ & 35 & $2.72 \mathrm{E}+12$ & 32 & $1.04 \mathrm{E}+13$ & 27 & $3.74 E+13$ & 18 & $2.36 \mathrm{E}+12$ & 21 & $3.45 E+14$ & 40 & $4.26 \mathrm{E}+11$ & 7 & $2.12 \mathrm{E}+13$ & 30 & $4.13 \mathrm{E}+14$ & 47 \\
\hline${ }^{*} \mathrm{HCO}_{3}^{-}$total & $9.19 \mathrm{E}+14$ & & $2.16 \mathrm{E}+13$ & & $1.54 E+14$ & & $9.37 \mathrm{E}+14$ & & $5.00 \mathrm{E}+13$ & & $2.97 E+15$ & & $3.30 E+13$ & & $3.80 E+14$ & & 3. $63 \mathrm{E}+15$ & \\
\hline $\mathrm{CO}_{2} \mathrm{sil}$ & $9.57 \mathrm{E}+13$ & 19 & $5.52 \mathrm{E}+12$ & 41 & $2.03 E+13$ & 23 & $1.69 \mathrm{E}+14$ & 30 & $3.19 \mathrm{E}+13$ & 78 & $1.05 E+15$ & 52 & $1.45 \mathrm{E}+13$ & 61 & $1.68 \mathrm{E}+14$ & 61 & $1.73 \mathrm{E}+15$ & 65 \\
\hline $\mathrm{CO}_{2}$ carb & $4.12 \mathrm{E}+14$ & 81 & $8.07 \mathrm{E}+12$ & 59 & $6.69 \mathrm{E}+13$ & 77 & $3.84 \mathrm{E}+14$ & 70 & $9.04 \mathrm{E}+12$ & 22 & $9.61 \mathrm{E}+14$ & 48 & $9.29 \mathrm{E}+12$ & 39 & $1.06 \mathrm{E}+14$ & 39 & $9.48 \mathrm{E}+14$ & 35 \\
\hline \multirow{2}{*}{$\begin{array}{l}\mathrm{CO}_{2} \text { atm } \\
\text { Fluxes }\end{array}$} & $5.07 \mathrm{E}+14$ & 55 & $1.36 \mathrm{E}+13$ & 63 & $8.73 E+13$ & 57 & $5.53 E+14$ & 59 & $4.09 \mathrm{E}+13$ & 82 & $2.01 \mathrm{E}+15$ & 68 & $2.38 \mathrm{E}+13$ & 72 & $2.74 \mathrm{E}+14$ & 72 & $2.68 \mathrm{E}+15$ & 74 \\
\hline & $\begin{array}{l}{ }^{*} 10^{3} \\
\mathrm{yr}^{-1}\end{array}$ & $\mathrm{~km}^{-2}$ & & & & & & & & & & & & & & & & \\
\hline $\mathrm{FCO}_{2}$ sil & 33.7 & & 37.5 & & 20.8 & & 36.2 & & 70.6 & & 41.6 & & 48.4 & & 71.4 & & 72.6 & \\
\hline F cationic carb & 144.8 & & 54.9 & & 68.5 & & 86.7 & & 20.0 & & 42.8 & & 31.1 & & 45.3 & & 39.7 & \\
\hline F cationic sil & 24.7 & & 27.9 & & 16.4 & & 26.0 & & 45.1 & & 27.7 & & 31.7 & & 46.7 & & 47.4 & \\
\hline $\begin{array}{l}\mathrm{F} \text { cationic sil spec. out- } \\
\text { crop }\end{array}$ & 38.0 & & 35.4 & & 22.9 & & 38.0 & & 45.3 & & 32.1 & & 31.7 & & & & 48.1 & \\
\hline cat. sil (Tonns yr-1) & 2194 & & 127 & & 478 & & 3838 & & & & 23343 & & & & 3712 & & 38347 & \\
\hline cat. sil $(\mu \mathrm{mol} y \mathrm{r}-1)$ & $7.01 \mathrm{E}+13$ & & 4.10E+12 & & $1.61 \mathrm{E}+13$ & & $1.21 \mathrm{E}+14$ & & $2.04 \mathrm{E}+13$ & & $6.98 \mathrm{E}+14$ & & $9.47 \mathrm{E}+12$ & & $1.10 \mathrm{E}+14$ & & $1.13 \mathrm{E}+15$ & \\
\hline
\end{tabular}

${ }^{*} \mathrm{HCO}_{3}^{-}$total $=\mathrm{Na}^{+}$sil $+\mathrm{K}^{+} \mathrm{sil}+2 \mathrm{Mg}^{2+}$ carb $+2 \mathrm{Ca}^{2+}$ sil $+2 \mathrm{Mg}^{2+}$ sil $+2 \mathrm{Ca}^{2+}$ carb; equation from Mortatti and Probst (2003).

${ }^{*} \mathrm{To}$ distinguish between the contribution of $\mathrm{Ca}^{2+}$ and $\mathrm{Mg}^{2+}$ from silicate and carbonate weathering in the investigated rivers (Lule River and Kalix River) the ionic ratio $\mathrm{Ca} / \mathrm{Na}=1.096$ and $\mathrm{Mg} / \mathrm{Na}=0.426$ were used from a nearby river (Råne River) which only has a silicate bedrock (see text for more information).

*Weathering mass budget $=$ mean element concentration * runoff volume - mean concentration in rain * precipitation volume.

\section{HESSD}

4, 555-588, 2007

\section{Weathering rates and origin of inorganic carbon}

J. Brink et al.

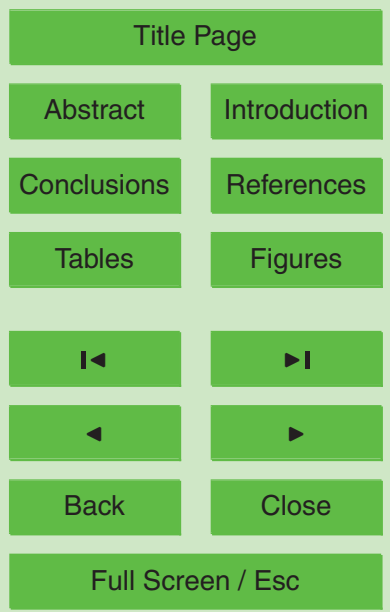

Printer-friendly Version

Interactive Discussion 


\section{HESSD}

4, 555-588, 2007

\section{Weathering rates and origin of inorganic carbon}

Table 6. Explanations of used abbreviations in formulas and text.

J. Brink et al.

\begin{tabular}{ll}
\hline Abbreviation & $=$ \\
\hline $\mathrm{F}_{\mathrm{Na}}$ sil & specific flux of sodium released by silicate weathering \\
$\mathrm{F}_{\mathrm{K}}$ sil & specific flux of potassium released by silicate weathering \\
$\mathrm{F}_{\mathrm{Ca}}$ sil & specific flux of calcium released by silicate weathering \\
$\mathrm{F}_{\text {cationic }}$ sil & specific flux of cations released by silicate weathering \\
$\mathrm{F}_{\mathrm{Ca}}$ carb & specific flux of calcium released by carbonate weathering \\
$\mathrm{F}_{\mathrm{Mg}}$ carb & specific flux of magnesium released by carbonate weathering \\
$\mathrm{F}_{\mathrm{cationic}}$ carb & specific flux of cations released by carbonate weathering \\
$\mathrm{F}_{\mathrm{HCO} 3}$ sil & specific flux of $\mathrm{HCO}_{3}$ released by silicate weathering \\
$\mathrm{F}_{\mathrm{HCO} 3}$ carb & specific flux of $\mathrm{HCO}_{3}$ released by carbonate weathering \\
$\mathrm{F}_{\mathrm{HCO} 3}$ rock weathering & specific flux of $\mathrm{HCO}_{3}$ released by carbonate and silicate weathering \\
\hline
\end{tabular}

Title Page

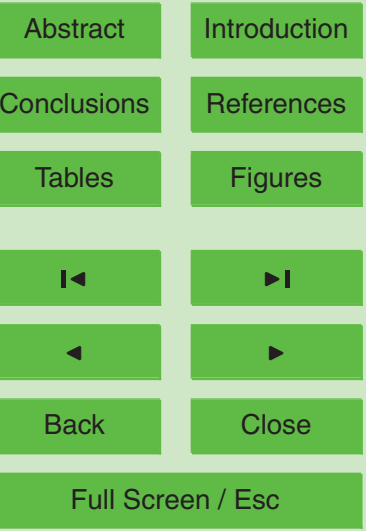

Printer-friendly Version

Interactive Discussion 
HESSD

4, 555-588, 2007

\section{Weathering rates and} origin of inorganic carbon

J. Brink et al.

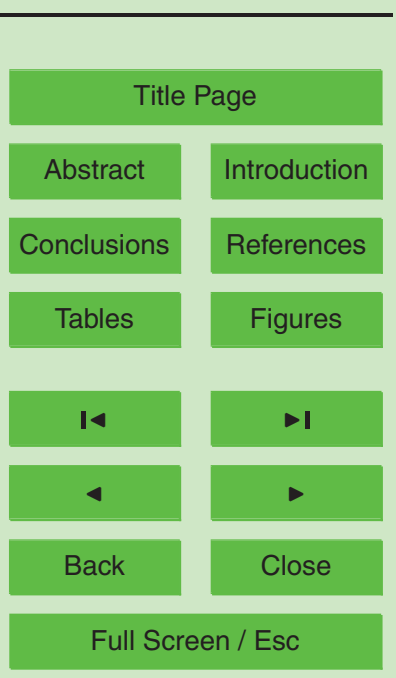

Printer-friendly Version

Interactive Discussion 


\section{HESSD}

4, 555-588, 2007

\section{Weathering rates and origin of inorganic carbon \\ J. Brink et al. \\ Title Page

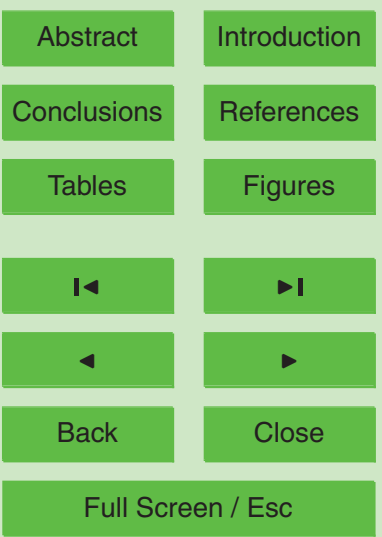

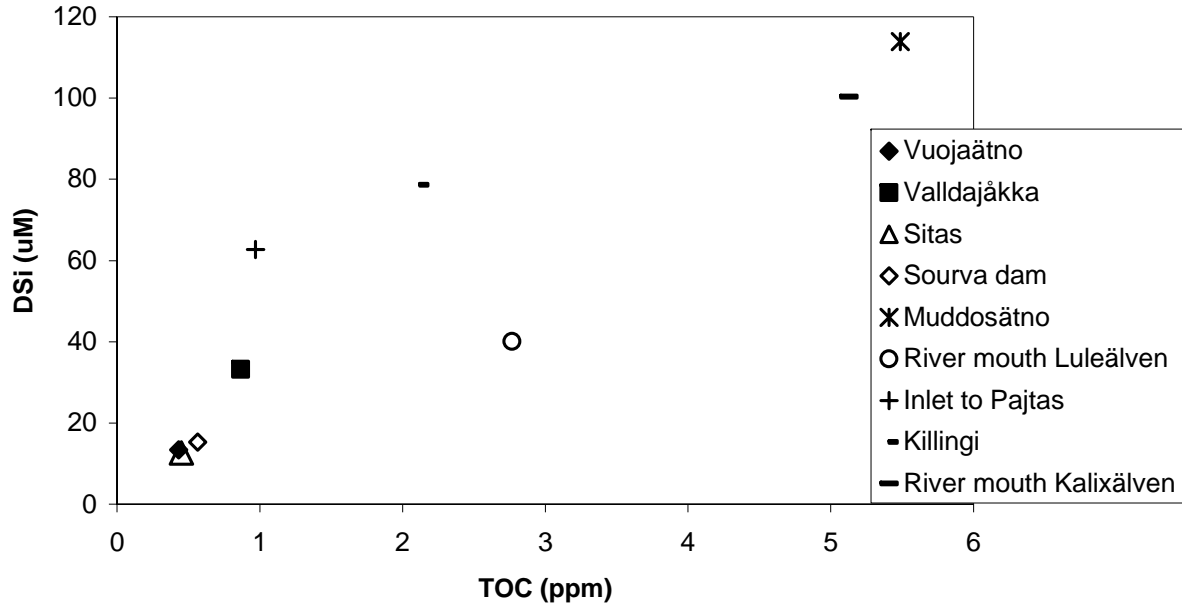

Fig. 2. Dissolved silicate (DSi) concentrations vs. Total organic carbon (TOC) concentrations in headwater tributaries, Akkajaure reservoir, Muddosätno and at river mouth of the Lule and Kalix River. Shown concentrations are yearly mean values.
Printer-friendly Version

Interactive Discussion 
(a)

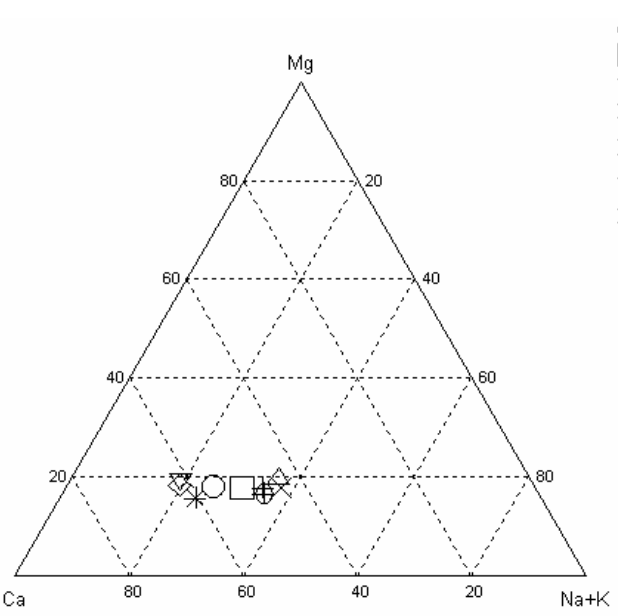

$$
\begin{aligned}
& \text { OInlet to Paitas } \\
& \square \text { Kaitum River } \\
& \text { Muddosätno } \\
& \text { † Lule River mouth } \\
& \text { KKalix River mouth } \\
& \text { * Sitas tunnel } \\
& \text { Suorva dam } \\
& \triangle \text { Valldajăkka } \\
& \nabla \text { Vuojätätno }
\end{aligned}
$$
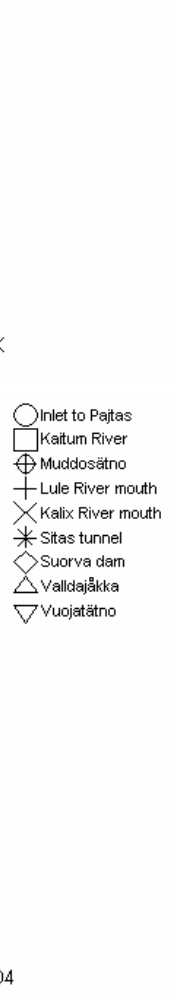

\section{HESSD}

4, 555-588, 2007

\section{Weathering rates and origin of inorganic carbon}

J. Brink et al.

Title Page

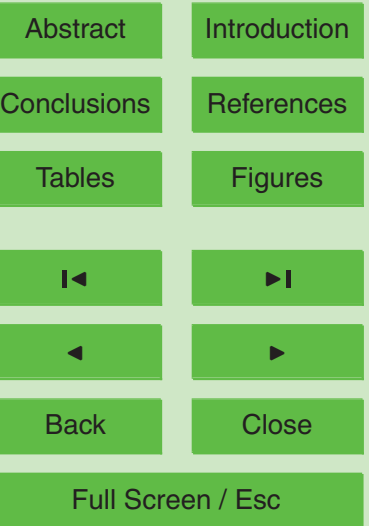

Printer-friendly Version

Interactive Discussion

Fig. 3. Plots are showing ternary diagrams over the water chemistry at sampled sites. 


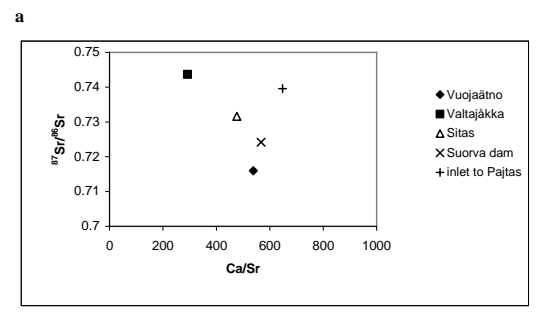

\section{HESSD}

4, 555-588, 2007

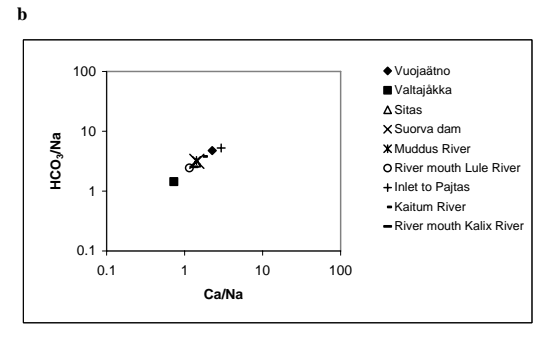

Weathering rates and origin of inorganic carbon

J. Brink et al.

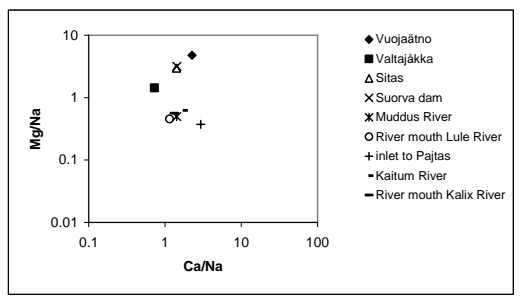

Title Page

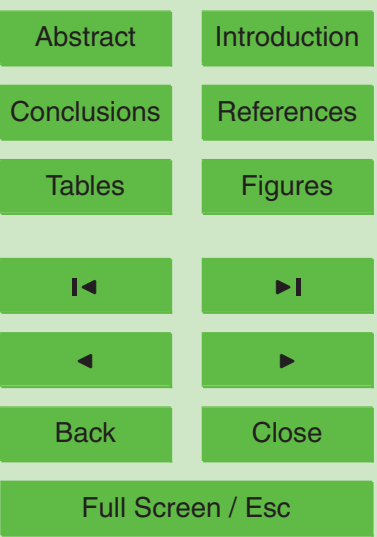

Fig. 4. Mixing diagrams for the main tributaries to the Akkajaure reservoir, Akkajaure reservoir and at the river mouth of Lule River, and the headwater and river mouth of Kalix River. The molar ratios are corrected for the atmospheric input. Voujaätno have a strong carbonate signature and is strongly influencing the water chemistry of the Akkajaure reservoir $(70 \%$ of the water in the Akkajaure reservoir is coming from Voujaätno). At the river mouth of Lule River the water has a more silicate weathering signature, like Kalix River, due to the weathering of Precambrian silicate rich basement in the forested lowland. 